NBER WORKING PAPER SERIES

\title{
USING DISCONTINUOUS ELIGIBILITY RULES TO IDENTIFY THE EFFECTS OF THE FEDERAL MEDICAID EXPANSIONS ON LOW INCOME CHILDREN
}

\author{
David Card \\ Lara D. Shore-Sheppard \\ Working Paper 9058 \\ http://www.nber.org/papers/w9058 \\ NATIONAL BUREAU OF ECONOMIC RESEARCH \\ 1050 Massachusetts Avenue \\ Cambridge, MA 02138 \\ July 2002
}

We are grateful to Barrett Graf and Pablo Ibarraran for outstanding research assistance, and to Ken Chay and David Lee for many helpful discussions. We have also received helpful comments from Janet Currie, Jonathan Gruber, Arleen Leibowitz, Robert Moffitt, and seminar participants at Berkeley, Williams, the Census Bureau, UCLA, and the NBER. This research was supported by the Center for Labor Economics at UC Berkeley, by the Joint Center for Poverty Research/U.S. Census Bureau Research Development Grant Program, and by the National Institute of Child Health and Human Development, Grant No. R01 HD3936901A1. The views expressed herein are those of the authors and not necessarily those of the National Bureau of Economic Research.

(C) 2002 by David Card and Lara D. Shore-Sheppard. All rights reserved. Short sections of text, not to exceed two paragraphs, may be quoted without explicit permission provided that full credit, including (C) notice, is given to the source. 
Using Discontinuous Eligibility Rules to Identify the Effects

of the Federal Medicaid Expansions on Low Income Children

David Card and Lara D. Shore-Sheppard

NBER Working Paper No. 9058

July 2002

JEL No. I18, I38

\begin{abstract}
This paper exploits the discrete nature of the eligibility criteria for two major federal expansions of Medicaid to measure the effects on Medicaid coverage, overall health insurance coverage, and the probability of visiting a doctor. The "100 percent" expansion, effective in 1991, extended Medicaid eligibility to children born after September 30,1983 in families below the poverty line. We estimate that this law led to about a 10 percentage point rise in Medicaid coverage for children born just after the cutoff date, and a similar or slightly smaller rise in overall health insurance. It also increased the fraction of children in the newly eligible group with a doctor visit in the previous year. The "133 percent" expansion, effective in 1990, extended Medicaid to children under 6 in families with incomes below 133 percent of the poverty line. This law had relatively small effects on Medicaid coverage for children near the eligibility limits, and little or no effect on health insurance coverage.
\end{abstract}

David Card

Department of Economics

549 Evans Hall \#3880

University of California Berkeley

Berkeley, CA 94720-3880

and NBER

card@econ.berkeley.edu
Lara D. Shore-Sheppard

Department of Economics

Fernald House

Williams College

Williamstown, MA 01267

and NBER

lara.d.shore-sheppard@williams.edu 
Concerns over the adequacy of health insurance coverage for low income children have transformed Medicaid from a narrowly targeted program for welfare recipients and the medically needy to a broad-based health insurance program for low-income families. Starting in the early 1980s a series of legislative changes allowed states to offer Medicaid coverage to children in married-couple families with incomes below the maximum limits for welfare, and to younger children in families with higher incomes. Two key laws at the close of the decade extended the program even further. Effective in 1990, states were required to offer Medicaid coverage to children under six in families with incomes up to 133 percent of the poverty line. A year later, coverage was mandated for children born after September 30, 1983 in families with incomes below the poverty line. ${ }^{1}$ Despite these expansions, health insurance coverage rates for children in families just under the poverty line remain below those of children in richer or poorer families. Figure 1, for example, shows the fraction of children with health insurance in different family income groups in 1989, 1993, and 1999. ${ }^{2}$ Coverage rates in all three years exhibit a U-shaped pattern, with the lowest rates for children of families with incomes from 75 to 100 percent of the poverty line - a range that is just above the welfare threshold in most states. Although this group experienced a modest rise in coverage between 1989 and 1993, the expansions only partially closed the gap between the welfare system and private health insurance.

Previous studies have examined the impacts of the Medicaid expansions and evaluated alternative explanations for the continuing coverage gap in Figure 1. Currie and Gruber (1996)

${ }^{1}$ In addition, states were granted the option of offering even more extensive coverage. See Section II for a more comprehensive discussion of the expansions.

${ }^{2}$ These data are drawn from the March 1989, 1993, and 1999 Current Population Surveys (CPS). The samples include individuals age 0-18 who are neither a family head nor a spouse of a head. See the Data Appendix for more information. 
estimated that the takeup rate for Medicaid among the newly-eligible population was relatively low - on the order of 20 percent. Cutler and Gruber (1996) argued that although the expansions increased the fraction of low-income children enrolled in Medicaid, they also led to reductions in the fraction covered by private health insurance, compounding the effect of low takeup rates. Subsequent research (Dubay and Kenney (1996), Shore-Sheppard (2000), Yazici and Kaestner (2000), Blumberg et al (2000), Ham and Shore-Sheppard (2001)) has confirmed the modest effect of the expansions on Medicaid coverage, while finding less consistent evidence of crowdout. A number of explanations - mainly focusing on the administrative burden of establishing and maintaining Medicaid coverage - have been offered for the apparently low takeup rate of coverage among groups made eligible by the recent expansions.

In this paper we re-examine the effects of the two major federal Medicaid expansions of the early 1990 s - the "133 percent" expansion covering children under the age of six, and the “100 percent" expansion covering children born after September 30, 1983. Results from an analysis of these two programs - one targeted at younger, somewhat more advantaged children, and the other aimed at older, poorer children - should provide useful insights about the likely success of the recent State Children's Health Insurance Program (SCHIP), which expanded eligibility even further up the income distribution. A key feature of the early 1990s expansions is the discontinuity in eligibility for children of different ages. ${ }^{3}$ Under the 133 percent provision, five year olds in families with incomes from 100 to 133 percent of the poverty line are eligible for Medicaid, whereas six year olds are not. Under the 100 percent provision, a child born in

${ }^{3}$ See Angrist and Krueger (1999) for a discussion of program evaluation methods that focus on "discontinuous" program eligibility rules, and a survey of recent applications. 
October 1983 whose family's income is below the poverty line is eligible for Medicaid, whereas a child born one month earlier is not. These rules allow us to construct simple comparisons between otherwise similar groups of eligible and ineligible children and construct new estimates of the effects of these expansions.

Our results, based on data from the Surveys of Income and Program Participation, the March Current Population Surveys, and the Health Interview Surveys, point to two main conclusions. First, the 100 percent expansion covering children born after September 30, 1983 led to about a 10 percentage point increase in Medicaid coverage among children in families just under the poverty line who were made eligible by the law, implying a takeup rate only one-half as large as the estimate of Currie and Gruber (1996). We find a similar or only slightly smaller effect on health insurance coverage, and evidence that the rise in coverage led to an increase in the fraction of children with at least one doctor visit in the previous year. Second, the 133 percent expansion had much smaller effects on Medicaid coverage, and little or no effect on health insurance coverage or the probability of visiting a doctor - at least for children near the eligibility threshold of the expansion. We also consider two explanations for the difference in takeup between the expansions: (1) that the richer families eligible for coverage under the 133 percent expansion had a relatively low probability of remaining Medicaid-eligible, and thus were less likely to enroll; and (2) that families eligible under the 133 percent expansion had less previous experience with means-tested benefit programs, and therefore had less knowledge about such programs or attached greater stigma to participating in them. We find only weak evidence for the first explanation, but somewhat stronger evidence for the second. 


\section{The Medicaid Expansions}

Medicaid eligibility for non-disabled children was originally limited to families receiving cash assistance under the Aid to Families with Dependent Children (AFDC) program. The first loosening of the links between AFDC and Medicaid occurred in 1984 with implementation of the "Ribicoff program" which allowed states to offer Medicaid to children in families that satisfied the income limits of the AFDC program, but not the family structure rules (i.e., children in twoparent families). Further decoupling occurred with passage of the Omnibus Budget Reconciliation Acts (OBRA) of 1986 and 1987. As described in Appendix Table 1, these laws permitted states to raise the income limits for Medicaid eligibility of pregnant women, infants, and young children over and above the limits for AFDC. OBRA 1987 also required the states to cover all children born after September 30, 1983 who lived in families with incomes below the AFDC income threshold, regardless of family structure.

The Medicare Catastrophic Coverage Act (MCCA, effective July 1989) and Family Support Act (FSA, effective October 1990), both passed in 1988, required states to extend Medicaid eligibility even further. The MCCA mandated eligibility for pregnant women and infants in families with incomes up to 75 percent of the poverty line, and permitted coverage of children up to age 8 in these families. The FSA required states to offer coverage to children in two-parent families in which the principal earner was unemployed.

Two further expansions of the Medicaid program - and the focus of the analysis in this paper - were included in OBRA 1989 and OBRA 1990. Effective April 1990, OBRA 1989 required states to offer Medicaid coverage to pregnant women and children up to age 6 with 
family incomes below 133 percent of the federal poverty level (the "133 percent expansion").

Effective July 1991, OBRA 1990 required states to cover children born after September 30, 1983 with family incomes below 100 percent of the federal poverty level (the " 100 percent expansion"). These children continue to be covered until they reach the age of $18 .^{4}$ We show in the next section that the laws raised the fraction of children eligible for Medicaid by about 6 percentage points - a substantial increase in the potential coverage of the program. ${ }^{5}$

\section{Measuring Medicaid Eligibility and Coverage}

\section{Data Sources}

We use three different surveys to measure the effects of the 1990 and 1991 expansions. Our main evidence is drawn from the first waves of the 1990-1993 Surveys of Income and Program Participation (SIPP). These data have the advantage that family income, composition, and program participation information all pertain to the month just before the interview (i.e., the fourth month of the panel), rather than to the previous calendar year, reducing the scope for recall errors and minimizing the gaps between Medicaid eligibility rules and observed characteristics. ${ }^{6}$

${ }^{4}$ Two other federal rule changes allowed the states to expand Medicaid eligibility. The "Section 1902(r)(2) option" allowed states to adopt more liberal standards for calculating income and resources for some categories of eligibility. The "Section 1115 waiver option" allowed states to apply for a research and demonstration waiver that would allow higher income limits for Medicaid.

${ }^{5}$ Similarly, Currie and Gruber (1996, Table 1) report a 7 percentage point rise in eligibility between March 1990 and March 1992.

${ }^{6}$ For these and other reasons, health insurance coverage is thought to be better-measured in the SIPP than the CPS, at least in the early 1990s. See Bennefield (1996) and Nelson and Mills (2001). 
A second feature of the SIPP (also shared by the Health Interview Survey) is that the public use samples report month and year of birth. This information allows us to form precise comparison groups of children on either side of the Medicaid eligibility thresholds.

The SIPP data also have some limitations. The samples are smaller than Current Population Survey or Health Interview Survey samples. Moreover, SIPP files do not identify state of residence for 9 smaller states (Maine, Vermont, Iowa, North Dakota, South Dakota, Alaska, Idaho, Montana, Wyoming). Since we need this information to assign AFDC and Medicaid eligibility, we exclude residents of these states from our SIPP analysis. Finally, SIPP samples are not available for every calendar year. To confirm the SIPP findings and provide a broader perspective, we use data from the 1990-1996 March Current Population Surveys (CPS) and the 1992-1996 Health Interview Surveys (HIS). The HIS includes information on recent doctor visits which we use as an indicator of health care access. ${ }^{7}$

From each of the three data sources we constructed samples of individuals age 18 or younger who were not heading their own families. The age, race, and ethnicity distributions of children in the three data sets are very similar (see Appendix Table 2 for details). The three data sets also give similar estimates of the family income distributions among children in the early 1990s. ${ }^{8}$ The SIPP and CPS show roughly comparable Medicaid coverage rates, and similar

${ }^{7}$ Currie and Gruber (1996) look at this measure as well as the probability of a doctor visit in the past two weeks, the probability of hospitalization last year, and the probability of visiting a doctor's office, hospital emergency room or clinic, or other site.

${ }^{8}$ See the Data Appendix for details on the calculation of family income in the three surveys. The similarity of the family income distributions in the SIPP and CPS is rather surprising given that the SIPP income data are for the previous month and the CPS data are for the previous year. Appendix Figure 1 of Card and Shore-Sheppard (2001) plots the distributions of family income relative to the family poverty standard in the two data sets. 
patterns of coverage across the family income distribution. The HIS shows Medicaid coverage rates comparable to those in the SIPP or CPS, but slightly lower overall health insurance coverage rates for low-income children.

Age, Income, Medicaid Eligibility, and Medicaid Participation

Table 1 presents an overview of the age, income, and Medicaid eligibility characteristics of our SIPP samples in 1990 through 1993. About one-third of the children in our sample are under the age of 6, and between one-third and one-half were born after September 30, 1983, depending on the survey year. These numbers suggest potentially large impacts of both the 133 percent expansion (for children under 6) and the 100 percent expansion (for those born after September 30, 1983). In the early 1990s, however, there was a substantial overlap between the groups. In 1992 - the first year affected by the 100 percent expansion - only 13 percent of the children were born after September 30, 1983 and were at least 6 years old. This fraction rose to 19 percent in 1993, and continued to rise over the remainder of the 1990s.

Medicaid eligibility under OBRA 1989 and OBRA 1990 is based on family income relative to the family poverty threshold. In 1990, the poverty rate of the children in our sample (i.e. the fraction with an income-to-poverty ratio under 100 percent) was 21.2 percent. ${ }^{9}$ Another 7.6 percent of children were in families with incomes between 100 and 133 percent of the poverty line. The fraction of children in poor families rose in the early 1990s, reflecting the cyclical downturn and other factors, while the fraction in families with income-to-poverty rates of 100-133 percent was relatively stable.

${ }^{9}$ The estimated child poverty rate in our March CPS sample was 21.6 percent in 1990. 
In classifying Medicaid eligibility it is useful to divide children in poor families into two groups: those with family incomes below the appropriate AFDC income threshold (based on state and family composition) and those with family incomes between the AFDC threshold and the poverty line. ${ }^{10}$ The former are nearly all eligible for Medicaid through AFDC (if the family is headed by a single woman) or AFDC-UP (if the state has an unemployed parent program) or through the "Ribicoff" program adopted by most states in the mid-1980s. ${ }^{11}$ The latter are only eligible through a poverty-based expansion. We use data on state benefit rates to assign each family an AFDC threshold. We then express this maximum eligibility cutoff as a fraction of the corresponding (family-specific) poverty line. In estimating AFDC income limits, a key issue is the amount of child care allowances that workers can deduct from their gross earnings. We assign the highest child care disregards that a family can potentially receive for children under 6 (see the Data Appendix), overstating the cutoffs for families that rely on unpaid child care.

The average AFDC income limit for our 1990 sample was 68.9 percent of the familyspecific poverty line. Over the next three years the AFDC limit fell relative to the poverty line, reflecting the erosion of the real value of benefits in many states and benefit cuts in some states. Despite this decline, the fraction of children living in families below the AFDC cutoff rose slightly, from 15.4 percent in 1990 to 17 percent in 1993 . The fraction in families above the AFDC limit but below the poverty line increased more, from 6.1 to 9.1 percent.

${ }^{10} \mathrm{~A}$ small fraction of families in high benefit-level states actually face AFDC thresholds that are above the family-specific poverty line.

${ }^{11} 85$ percent of our 1990 SIPP sample resided in states with Ribicoff rules allowing Medicaid eligibility regardless of family structure for all families with incomes below the AFDC limit. 
In the absence of poverty-based expansions, the family income limit for Medicaid would equal the AFDC limit. State and federal programs in place in 1990 raised the average Medicaid limit 7.6 percentage points above the average AFDC limit, and extended coverage to about 1.7 percent more children than were eligible under the AFDC limits. In all, about 10 percent of children who were financially eligible for Medicaid in 1990 were eligible under poverty-line related expansion programs. Over the next three years, the OBRA 1989 and OBRA 1990 expansions, coupled with state-level programs, raised the average Medicaid income cutoff to 112 percent of the poverty line, and raised the fraction of Medicaid-eligible children in families with incomes over the AFDC threshold to 40.8 percent.

The final rows in Table 1 present data on AFDC and Medicaid participation. AFDC participation rose faster than estimated eligibility in the early 1990s, from 8.4 percent in 1990 to 12 percent in 1994. The fraction of children covered by Medicaid and not on AFDC increased even faster, from 3.7 percent to 7.7 percent. As a result, the share of Medicaid recipients from outside the welfare system rose from 30 percent in 1990 to 40 percent in 1993. Data from the March CPS show a similar rise, from 31 percent in the March 1990 CPS to 44 percent in the 1993 CPS.

The results in Table 1 suggest that the Medicaid expansions of the early 1990s raised eligibility, leading to a rise in the fraction of Medicaid recipients from outside the traditional base of welfare recipients. At the same time, increasing welfare participation also contributed to the growth in Medicaid caseloads. A more detailed look at changes in Medicaid eligibility and coverage is presented in Table 2 . Here, we use a simple hierarchy to assign the sources of Medicaid eligibility: (1) eligible under the AFDC income limits; (2) eligible through a federal or 
state program for infants; (3) eligible under the 133 percent program for children under age 6; (4) eligible under the 100 percent program for children born after September 30, 1983; or (5) eligible under a state program that provides coverage beyond the federal programs. Due to data limitations we ignore eligibility for disabled children and those whose families have incurred large medical expenses. For each eligibility group we show the fraction of children in the group and the Medicaid coverage rate (or takeup rate). The right-hand columns of the table also report the change in overall Medicaid participation attributable to the trend in Medicaid recipiency within the group. ${ }^{12}$ Expansions in Medicaid coverage should not necessarily affect Medicaid takeup among groups that were previously eligible. Arguably, then, these changes should be factored out of the rise in Medicaid in assessing the effect of the expansions. On the other hand, eligibility is measured with error, and takeup by newly-eligible children who are mis-assigned to the ineligible or AFDC-related eligibility groups may cause measured takeup rates for these groups to rise.

This phenomenon could partially explain the rise in Medicaid coverage among children we estimate to be ineligible for coverage, from 3.5 percent in 1990 to 5.1 percent in $1993 .^{13}$ Although the takeup rate of the ineligible group is low, the group is large, and the rise in their coverage accounts for 1.1 percentage points (or 15 percent) of the overall rise in Medicaid

\footnotetext{
${ }^{12} \mathrm{We}$ calculate this as the change in the participation rate of the group, multiplied by the group's population share in 1993. Using the 1990 shares leads to slightly different within-group changes.

${ }^{13}$ Even if eligibility is correctly assigned, errors in reported Medicaid coverage will lead to some measured coverage among the ineligible group. Card, Hildreth, and Shore-Sheppard (2001) estimate that the false positive rate of Medicaid reporting by lower-income children in the SIPP is between 2 and 5 percent - enough to explain the mean level of reported coverage among the ineligible population, but not the rising trend.
} 
participation. ${ }^{14}$ A similar trend of increased Medicaid coverage is evident among children in families with incomes below the AFDC threshold. The Medicaid participation rate of children in female-headed families with incomes below the AFDC limit rose by 10 percentage points, contributing 1.1 percentage points to the overall rise in Medicaid. ${ }^{15}$ For children in other types of families (e.g., dual headed and single-father families) with incomes under the AFDC limit there was a 20 point rise in takeup, accounting for an additional 1.2 percentage points of the rise in Medicaid. ${ }^{16}$ Finally, there was also a rise in participation among the roughly 1 percent of children covered by federal and state infant programs.

The fifth and sixth rows in Table 2 present data on children eligible under the OBRA 1989 and OBRA 1990 programs. The 133 percent program became effective in April 1990. Three quarters of the 1990 SIPP sample were interviewed before this date, leaving only one quarter potentially eligible for coverage under the new program. By 1993, however, the fraction eligible had risen to 4.1 percent. The 100 percent program became effective in July 1991 , so

${ }^{14}$ As we are unable to identify disabled children who may be eligible for Medicaid through the Supplemental Security Income (SSI) program, some of the increase in participation among the apparently ineligible may be due to the increase in disability rates and SSI participation that occurred over this period (see for example Kaye et al. (1996) and Kubik (1999)). An advantage of using the discontinuities in the Medicaid expansions to identify the expansions' effect is that trends such as increasing SSI participation will not confound our estimates of the impact of the poverty-related expansions.

${ }^{15}$ The rise in Medicaid for this group parallels a rise in AFDC participation, from 60.7 percent in 1990 to 69.9 percent in 1993.

${ }^{16}$ About 90 percent of these children are in Ribicoff states, and so were eligible for Medicaid throughout the sample period. The levels and trends in Medicaid participation for children in Ribicoff and non-Ribicoff states are nearly identical. In addition to the Ribicoff program, children in dual-headed families may be enrolled in Medicaid via the AFDCUnemployed Parent program, or via AFDC if the "father" is actually a stepfather (Moffitt, Reville, and Winkler (1994)). 
only the children in our 1992 and 1993 samples were potentially eligible for this expansion. Because of the overlap in age coverage of the 133 percent and 100 percent programs, and the modest gap between the AFDC income limits and the poverty line (see Table 1), less than two percent of children in the later SIPP's gained eligibility because of the 100 percent program. Interestingly, the Medicaid takeup rate for the 100 percent program eligibility group is higher than the rate for the 133 percent eligibility group, although both are below the rate among the traditional AFDC-related eligibility group. Thus, as noted by Currie and Gruber (1996) and Shore-Sheppard (1997), the marginal takeup rate of Medicaid among children made newly eligible by the expansions was below the average takeup rate.

Although OBRA 1986 permitted states to offer Medicaid coverage to children in families with incomes over the AFDC limit, less than 1 percent of children were eligible under such programs in early 1990. Over the next few years, however, many states began to implement coverage expansions that went beyond the minimum federal requirements. Some of these programs only covered certain categories of medical expenses, or required co-payments. By 1993, we estimate that optional state programs offered potential coverage to about 5 percent of children who were otherwise ineligible for Medicaid. As shown in Table 2, the takeup rate for this group was low, potentially reflecting the restrictive nature of some of the programs and/or a lack of knowledge about them.

The results in Table 2 point to three main conclusions. First, the rise in Medicaid coverage in the early 1990 s was driven by a combination of rising participation among groups that were already eligible, expansions of eligibility, and a rise in participation among children that appear to be ineligible. Given errors in imputing eligibility, it is hard to assess whether the 
rises in participation among ineligible and AFDC-eligible children should be attributed to the expansions, or to a general trend toward higher takeup of welfare programs. Second, prior to the effective dates of the 133 percent and 100 percent federal expansions, optional state expansions covered a very small fraction of children in families with incomes beyond the AFDC limit (less than 1 percent), although subsequent state programs extended coverage further. Third, by 1993, the 133 percent program offered coverage to about 4 percent of children in families with incomes above the AFDC limit, while the 100 percent program expanded coverage to an additional 2 percent of children.

\section{The 100 Percent Program}

We begin our analysis of the federal Medicaid expansions by considering the effect of the 100 percent program. To set the stage, Figure 2 shows Medicaid eligibility rates by quarter of birth for children just under the poverty line (with family incomes from 60-99 percent of poverty) and just over the line (100-140 percent of poverty) in our 1992 and 1993 SIPP samples. Since most children in families with incomes below the AFDC limit were eligible for coverage before the 100 percent program, we exclude anyone whose family-specific AFDC cutoff is above 70 percent of the poverty line. ${ }^{17}$ The graph illustrates the sharp discontinuity in Medicaid eligibility induced by the expansion. Among children in families below the poverty line but above the AFDC income limit, Medicaid eligibility rates average 6-8 percent for those born before the

\footnotetext{
${ }^{17}$ An examination of AFDC participation rates shows that welfare participation falls off very quickly once the income-to-poverty rate is within 10 percent of the AFDC cutoff - see Card and Shore-Sheppard (2001, Figure 2). The fall-off before the cutoff presumably reflects the fact that our calculations overstate the AFDC income limit. We build this 10 point gap into our sample exclusion.
} 
fourth quarter of 1983, and 100 percent after. Among children in families just above the poverty line, eligibility rates are about 6-8 percent on either side of the 1983-III breakpoint. Since nearly all the children in the above-poverty group are eligible under the 133 percent program if they are under 6 years of age, the average eligibility rate for the above-poverty group rises to nearly 100 percent for those born 12-16 quarters after 1983-III.

Figure 3 shows corresponding patterns of Medicaid coverage. There is a discernable "jump" in Medicaid coverage for the below-poverty group between the 1983-III and 1983-IV birth cohorts, with no such jump for the above-poverty group. Moreover, coverage rates of the below poverty group are fairly stable on either side of the eligibility cutoff, suggesting that the jump is not just a random blip. ${ }^{18}$ In contrast to the rise at 1983-III, there is no rise in coverage for the above-poverty group born 12-16 quarters after 1983-III, despite the steep rise in eligibility noted in Figure 2. This is consistent with other evidence (discussed below) that the 133 percent expansion had very small effects on Medicaid coverage.

The rules of the 100 percent expansion also create discontinuities in eligibility by family income. In particular, for children born after September 1983, one would expect Medicaid coverage rates to fall as family income passes through the poverty line. Figure 4 graphs Medicaid coverage rates by family income for children in the 1992 and 1993 SIPP samples born before and after the OBRA 1990 cutoff date. ${ }^{19}$ A key difference between these comparisons and

${ }^{18}$ There are 25-30 children per birth quarter in the 60-99 percent poverty group in the combined 1992 and 1993 SIPPs. Thus, the standard error of the estimated Medicaid participation rate for a single birth-quarter is about 8 percentage points.

${ }^{19}$ As in Figure 3 , the samples used in Figure 4 exclude children whose AFDC cutoff is greater than 70 percent of the family-specific poverty line. 
the comparisons by birth quarter in Figure 3 is that family incomes (unlike birth dates) vary from month to month. ${ }^{20}$ Since enrolling in Medicaid is burdensome, families will not necessarily enroll if their incomes are only temporarily low, leading to some fuzziness in the discontinuity by income. Consistent with this reasoning, there is a smoother rise in Medicaid coverage around the poverty line in Figure 4 than at the 1983-III cohort cutoff in Figure 3. Nevertheless, the patterns of Medicaid coverage for the older and younger cohorts in Figure 4 suggest that the 100 percent program has a significant effect. Above the poverty line, Medicaid coverage rates are fairly similar for the older and younger cohorts. Below the poverty line the coverage rate of the younger cohort is 10 percentage points higher.

\section{Differences-in-Differences and Regression-Discontinuity Estimates}

The evidence of discontinuities in Figures 3 and 4 can be evaluated more formally. One way is to compare the differences in Medicaid coverage and related outcomes for children in families just above and just below the poverty line who were born before and after September 30, 1983. The components of these "differences-in-differences" are presented in Table 3, using the same samples underlying Figures 3 and 4. For children in the later cohort we show means for all age groups and for the subset who are age 6 or older as of the SIPP survey. Focusing on children 6 or older eliminates the problem that most of the younger children in the higher-income group are eligible for Medicaid through the 133 percent expansion.

${ }^{20}$ See for example Pischke (1995), who fits a variety of models to monthly family income from the SIPP. In our samples, the correlation of monthly family incomes measured 6 months apart is around 0.80 . 
The eligibility rates in the third column of the table show that children born before October 1, 1983 have very low rates of Medicaid eligibility, regardless of whether their family income is above or below the poverty line. ${ }^{21}$ Children born after the cutoff date in poor families are all eligible for Medicaid. Children born after the cutoff in families just above the poverty line but over age 6 also have very low rates of Medicaid eligibility. However, because of the 133 percent program, if younger children are included the average Medicaid eligibility rate of the higher-income group rises to 50.8 percent. Thus, if the comparisons are restricted to children over 6, the difference in differences in eligibility is 92 percent, while if younger children are included it falls to 47 percent. The gap reflects the "contamination" of the above-poverty/postSeptember 1983 group by children who are eligible under the 133 percent program.

One way to focus more directly on the discontinuity is to construct regression-adjusted differences in differences that include smooth functions of age and income, as well as controls for age under 6 and other factors. In particular, consider the following regression model for the event of Medicaid eligibility, or any related outcome (e.g. Medicaid coverage):

$$
\begin{aligned}
Y=a & +b_{1} \text { Poor }+b_{2}(\text { Born After } 9 / 30 / 83)+b_{3} \text { Poor } \times(\text { Born After } 9 / 30 / 83) \\
& \left.+b_{4}(\text { Age }<6)+b_{5}(\text { Age }<6) \times(1 \text {-Poor })+\text { G(Age, Income }\right)+d X+e,
\end{aligned}
$$

where "Poor" is an indicator for family income under the poverty line, "Age" represents an individual's age, "Income" represents family income relative to the poverty line, G( ) is some smooth function of age and income (e.g. a low order polynomial), and $\mathrm{X}$ is a set of other characteristics (e.g., year dummies and controls for race and ethnicity) This specification allows the outcome variable $\mathrm{Y}$ to vary smoothly with age and family income, and to exhibit possible

\footnotetext{
${ }^{21}$ Nearly all of the eligible children in this cohort were eligible under state programs.
} 
discontinuities as family income reaches the poverty line, or the child's birth date approaches September 30,1983 , or the child reaches age 6 . The impact of the 100 percent program is identified by the coefficient of the interaction between poverty status and birth cohort. Any confounding effect of the 133 percent program is captured by the coefficient $b_{5}$ of the interaction between age under 6 and above-poverty status. ${ }^{22}$

Note that if only the first three terms of equation (1) are included, then the coefficient $b_{3}$ of the interaction between poverty status and the indicator for born after September 1983 is just the difference in difference. The addition of the $G($ ) function controls for any systematic variation in the outcome by age or income, and shifts the source of identification from a "global" difference in differences to a local one, concentrated around the eligibility threshold. The addition of other covariates helps to control for factors such as region or time effects that might be differentially distributed across the four groups in the difference-in-differences comparison.

The regression-adjusted differences in differences in Table 3 include a cubic in age, a quadratic in income (relative to poverty), dummies for race, Hispanic ethnicity, and living with a single mother, and interactions of year effects with 4 region effects. Looking at the eligibility models, when the comparison is restricted to children age 6 and older, the regression-adjusted estimate of the eligibility effect is nearly identical to the unadjusted difference in differences (92 percent). When the sample includes children under 6 , the adjusted estimate is also very close to 92 percent, suggesting that the controls effectively shift the identification to the eligibility threshold.

\footnotetext{
${ }^{22}$ Nearly all the children in our higher income group under the age of 6 are eligible under the 133 percent expansion.
} 
The models for Medicaid coverage confirm the visual impression from Figures 3 and 4 that the 100 percent expansion led to a 10 percentage point rise in coverage for children close to the eligibility limits. As with the eligibility models, the coverage effects from the regressionadjusted models are similar whether or not children under 6 are included. Since the 100 percent program increased eligibility by about 92 percent and increased coverage by 10 percent, the implied takeup rate among the newly eligible group is 11 percent (with a standard error of 4.2 percent) - substantially below the 20 percent takeup rate estimated by Currie and Gruber (1996) for the combined federal and state expansions over the $1985-93$ period. ${ }^{23}$

The other models in Table 3 analyze AFDC participation, Medicaid coverage outside of AFDC, overall health insurance coverage, and the presence of non-Medicaid insurance. The results for AFDC and for Medicaid coverage outside of AFDC can be interpreted as specification checks. In principle, the change in the Medicaid income limit should not have affected AFDC participation: thus, all of the rise in Medicaid associated with the rise in eligibility should have occurred outside AFDC. This is confirmed by the unadjusted and regression-adjusted differences in differences.

The results for any health insurance, and for other (i.e., non-Medicaid) insurance, address the issue of crowd out. The unadjusted difference in differences that includes children under 6 shows some evidence of crowd out, with a smaller rise in total coverage than in Medicaid, and a

${ }^{23}$ Taking the ratio of the coverage and eligibility effects is equivalent to an instrumental variables (IV) estimate of the effect of Medicaid eligibility on Medicaid coverage, using the interaction of poverty status and pre-September 1983 birth cohort as an instrument for eligibility. The corresponding OLS estimate is 8.1 percent with a standard error of 2.7 percent. 
decline in other coverage. ${ }^{24}$ However, our preferred specifications that either exclude children under 6 or add controls for age, income, and coverage under the 133 percent program show no such patterns

We have performed a number of specification tests to probe the validity of the methods used in Table 3. One test is to perform the same analysis using data from 1990 and 1991, before the 100 percent program took effect. Unfortunately, this exercise is not very informative because there are very few children in the right income range who were at least 6 years old in 1990 or 1991 and were born after September 1983 (a total of only 121 observations). Using this small sample, the difference in differences in Medicaid coverage prior to the effective date of the 100 percent expansion is actually negative (but statistically insignificant). The negative "pre-program treatment effect" is attributable to a gap in AFDC participation: the difference in differences of Medicaid participation outside of AFDC is close to zero.

A second test is to drop the exclusion restriction that eliminates children in high-AFDC benefit states. The main impact of this change is to raise the Medicaid eligibility and participation rates of the below-poverty group born before October 1983. As a consequence, the regression-adjusted difference in differences in eligibility falls to 66.3 percent, the corresponding effect on Medicaid coverage falls to 8.8 percent (standard error 3.4), and the effect on overall health insurance falls to 8.8 percent (standard error 3.6). For this broader sample the implied takeup rate of Medicaid coverage by newly eligible children is 13.3 percent (standard error 5.2 percent) - quite similar to the estimate using the narrower sample, as would be expected if all the

\footnotetext{
${ }^{24}$ Some children have both Medicaid and other coverage. Thus, the coefficients for Medicaid coverage and non-Medicaid coverage do not "add up" to the coefficient in the model for any coverage.
} 
changes in the broader sample are generated by behavioral reactions among children above the AFDC limit.

A third test is to augment the sample for 1992 and 1993 with data from the earlier panels. For example, month 16 of the 1991 panel represents the same calendar period as month 4 of the 1992 panel. We included these data (for the 90 percent of the 1991 panel who were still in the sample at their $16^{\text {th }}$ month) and re-estimated the models in Table 3. The results are very similar to those in Table 3, and slightly more precise. For example, the regression-adjusted estimate of the Medicaid coverage effect is 10.8 percent (standard error 3.4) while the corresponding estimate of the overall health insurance effect is 9.2 percent (standard error 4.0). Adding in data for month 28 of the 1990 panel similarly has very little effect on the character of the results.

\section{The 133 Percent Expansion}

Like the 100 percent expansion, the 133 percent Medicaid expansion generates sharp discontinuities in Medicaid eligibility along both age and income dimensions. As a first step in evaluating this expansion, we compare children older and younger than 6 in families with incomes from 100 to 132 percent of the poverty line in the 1991-93 SIPP, against similar age groups in families with incomes from 133 to 166 percent of the poverty line. Figure 5 shows Medicaid coverage rates by age measured in quarters for the two groups, using data from the 1991-1993 SIPP samples. $^{25}$ Unlike Figure 3, there is no evidence of a jump in Medicaid

${ }^{25}$ To avoid issues of AFDC eligibility, the underlying samples exclude children in families whose AFDC income limit is above 100 percent of the poverty line. This affects a relatively small number of children. 
coverage associated with the age limit of the 133 percent program ${ }^{26}$. A graph of Medicaid coverage by family income similarly shows no evidence of a drop in coverage as income reaches 133 percent of poverty.

Table 4 presents means of Medicaid eligibility and coverage for children older or younger than 6 in families with incomes just below and just above the cutoff of the 133 percent program. We also show the associated differences in differences, following the same format as Table 3. Both the unadjusted and adjusted differences in differences show that the 133 percent expansion raised Medicaid eligibility of the target group by about 85 percent. Unlike the 100 percent expansion, however, there was no corresponding effect on Medicaid coverage or health insurance coverage. To check whether these estimates might reflect a slow diffusion of knowledge about the 133 percent program, we constructed differences in differences using data for 1992 and 1993 only. The results, shown in the bottom row of Table 4, are not much different from the results based on 1991-1993. We also tried various changes in the sample (e.g., narrowing the income limits of the affected and unaffected groups around the 133 percent income cutoff; and narrowing the age range), but found no changes in the results.

A limitation of the analysis in Table 4 is that it focuses on only some of the children who were affected by the 133 percent expansion - those in families with incomes from 100 to 133 percent of poverty. The program also extended coverage to children under the age of 6 with family incomes below the poverty line. By pooling different age and income groups and including indicators for potential eligibility under either or both expansions, it is possible to

\footnotetext{
${ }^{26} \mathrm{As}$ in Figure 3, the lines in Figure 5 are smoothed using a 3-quarter moving average
} with weights $(0.2,0.6,0.2)$. There are $40-50$ observations per quarter for both income groups, slightly more than in the samples in Figure 3. 
determine whether this group responded more like the older group affected by the 100 percent expansion, or more like the higher income group affected by the 133 percent expansion. The results of this exercise - using SIPP data for 1992 and 1993 for children with family incomes from 60 to 166 percent of the poverty line - are reported in Table 5. For simplicity, we report only the coefficients of the potential eligibility indicators from regression-adjusted models that control for age, income, demographic characteristics, and region and year effects.

The results in the first column show that potential eligibility under the 100 percent expansion, or under both expansions, was associated with about a 66 percent increase in Medicaid eligibility, whereas potential eligibility under the 133 expansion was associated with an 83 percent rise in eligibility. The smaller effect for the 100 percent and combined expansions reflects the fact that about one quarter of children in families with incomes between 60 and 100 percent of poverty had family incomes under the AFDC limit and were therefore already eligible for Medicaid. In terms of Medicaid coverage, the estimates in Table 5 show that children who were eligible for the 100 percent expansion only, or for both expansions, had 9-10 percentage point gains in Medicaid coverage, while those who were eligible for the 133 percent expansion had a slight decline in Medicaid coverage. In all three cases there is no significant effect on AFDC participation. The results for the probability of any health insurance hint at a possible difference between the older children eligible for the 100 percent expansion only, and the younger children eligible for both. Specifically, the rise in overall insurance coverage for the 100-percent-only group is about the same size as the rise in Medicaid, implying (as in Table 3) that there was little or no crowd-out for this group. By comparison, non-Medicaid insurance coverage among the younger children affected by both expansions fell, leading to a smaller gain 
in overall coverage than in Medicaid. It should be noted, however, that the differences between the coefficient estimates for the 100-percent-only group and the group eligible for both expansions are statistically insignificant, as shown by the probability values reported in the bottom row of the Table.

To summarize, the results in Tables 3, 4, and 5 indicate that the 100 percent expansion led to about a 10 percentage point rise in Medicaid coverage and overall health insurance coverage among previously ineligible children, whereas the 133 percent expansion had little effect on either. Impacts for the set of younger children covered by both expansions are about the same as for those covered by the 100 percent program only, although this group shows slightly more evidence of crowd-out.

\section{Evidence from the March CPS}

In view of the surprising results for the 133 percent expansion obtained from our SIPP samples, we decided to look at the program using March CPS data. Since the age limit of the 133 percent expansion falls at exactly 6 years, it is possible to distinguish eligible and ineligible children using age data measured only in years. The results are summarized in Table 6. Despite some small differences in the levels of Medicaid, AFDC, and health insurance coverage in the CPS and SIPP, the differences-in-differences are very similar. In particular, March CPS data from 1991-93 suggest that the 133 program had a very small effect on Medicaid coverage of children under 6 in families with incomes from 100-133 percent of poverty - on the order of 2 percent or less. Despite the much larger CPS sample sizes, none of the differences-in-differences is statistically significant, with the exception of the -3.9 percent effect on other health insurance. 
Paradoxically, the CPS data suggest that the 133 program caused other insurance coverage to fall by more than the rise in Medicaid, leading to a net loss in overall health insurance coverage. We also conducted a year-by-year analysis using the CPS files for 1991 to 1996, to check if the impact of the 133 expansion changed over time. The results are summarized in Appendix Table 3. While there is some year-to-year variation, on balance we see no systematic effects of the 133 percent expansion on Medicaid participation or overall health insurance coverage of children close to the eligibility limits of the law.

\section{Evidence from the Health Interview Survey}

Our final set of estimates is based on data from the 1992-1996 Health Interview Surveys. We focus on three key dependent variables from the HIS: Medicaid coverage, any health insurance coverage, and the number of doctor visits in the past year. Following previous researchers (Holl et al., 1995; Currie and Gruber, 1996), we distinguish between children who had at least one doctor visit last year, and those who did not, and interpret the incidence of at least one doctor visit as an indicator of access to preventative medical care.

The upper panel of Table 7 reports unadjusted and regression-adjusted difference-indifferences estimates of the effect of the 100 percent poverty expansion, using children in families with incomes from 60 to 140 percent of poverty born before and after September 30, 1983. ${ }^{27}$ (The adjusted models include the same set of control variables used in Table 3 for our

\footnotetext{
${ }^{27}$ Since the the public-use samples of the HIS do not report state of residence, we cannot construct family-specific AFDC income cutoffs and eliminate children with high AFDC thresholds who were eligible for Medicaid even before the exansion. As described in the Data Appendix, we estimate the ratio of family income to poverty using income intervals reported in the HIS and family size information. We exclude the roughly 15 percent of individuals with
} 
analysis of the SIPP). The estimated effects on Medicaid coverage and overall insurance coverage are slightly smaller than for comparable samples of the 1992-93 SIPP, and more precise. $^{28}$ The adjusted HIS estimates suggest that the 100 percent expansion raised Medicaid coverage by 6 percentage points and raised health insurance coverage by about 5 percentage points, although the gap - which is an estimate of the crowdout effect - is not significant $(t=0.8)$. The impact of the expansion is illustrated in Figure 6, which plots Medicaid coverage rates by quarter of birth for children in families just below and just above the poverty line. As in Figure 3, there is a noticeable jump in Medicaid coverage after the September 30, 1983 eligibility date for the poorer children, and no such jump for the richer children.

The results in the third column of Table 7 suggest that the 100 percent expansion also had a positive effect on health care utilization. The unadjusted effect is not quite statistically significant, while the regression-adjusted effect is marginally so, with a t-ratio of $2.18 .^{29}$ Considering the rather modest estimate of the expansion's effect on insurance coverage, the effect on doctor visits is relatively large. Specifically, the estimates suggest that children with newly available health insurance coverage have a $60 \%$ higher probability of at least one annual

missing family income information.

${ }^{28}$ The effects for the 1992-93 SIPP using a comparable sample are 8.8 percent on Medicaid coverage (standard error 3.4) and 8.8 percent on overall health insurance coverage (standard error 3.6). We cannot estimate the effects of the expansions on eligibility in the HIS since we do not know state of residence and therefore cannot assign eligibility for those with incomes under the AFDC income limits. However, assuming the eligibility effect is the same as in the SIPP (66 percent), the implied takeup rate for the HIS sample is about 9 percent.

${ }^{29}$ The mean fractions of children with at least one doctor visit in the previous year for the four groups used in the difference-in-differences are as follows: poor children born before October $1983-65.2 \%$; poor children born later $-83.1 \%$; above-poverty children born before October $1983-65.6 \%$, above poverty children born later $-81.6 \%$. 
doctor visit than in the absence of the expansion, although this estimate is rather imprecise (standard error 31\%). This is the instrumental variables estimate of the effect of health insurance coverage on the probability of visiting a doctor at least once, using the interaction of poor and born after September 1983 as an instrument for coverage. By comparison, an OLS regression of doctor visits on insurance coverage and the same set of control variables has a coefficient of only 12 percent (standard error 0.6 percent).

The models in the lower panel of Table 7 examine the combined effects of the 100 and 133 percent expansion, using the same framework as in Table 5. The results are comparable to those based on the SIPP, although in the HIS sample there is more evidence of an effect of the 133 percent program on Medicaid coverage. Interestingly, however, this increase in Medicaid was not associated with a significant rise in overall health insurance coverage, or with a significant change in the probability of visiting a doctor. ${ }^{30}$ It is also interesting that although the SIPP sample showed larger crowdout effects of the 100 percent expansion for younger children who were also eligible for the 133 program, in the HIS sample the opposite is true: any evidence of crowdout is confined to the older children who were excluded from the 133 percent program.

Overall, we interpret the HIS results as supportive of our findings from the SIPP and CPS, although differences across the various specifications suggest the need for caution in drawing strong conclusions from any one data set. Based on the three data sets we conclude that the 100 percent program had a larger effect on Medicaid and health insurance coverage than the

${ }^{30}$ If we examine the 133 program separately looking at children with incomes from 100 to 166 percent of poverty, as in Tables 4 or 6 , we obtain estimates of the effects on Medicaid and overall health insurance coverage nearly identical to those reported in Table 7 for the 133percent-only group. 
133 percent program. In fact, the 133 percent expansion seems to have had no effect on total health insurance coverage, implying that any impact on Medicaid was offset by reductions in other coverage. Evidence of crowd-out effects from the 100 percent expansion varies slightly across data sets. The SIPP shows little or no crowdout effects among older children covered by the 100 percent expansion, but some crowdout for younger children, whereas the HIS shows the opposite pattern. In neither case, however, are the crowdout estimates statistically significant. Finally, HIS data suggest that the 100 percent expansion led to a sizeable increase in the fraction of newly-covered children who visited a doctor at least once in the previous year.

\section{Explanations for Differential Takeup of the 100 Percent and 133 Percent Expansions}

The contrast between the modest but positive impacts of the OBRA 1990 expansion and the more limited effects of the OBRA 1989 expansion raises the question: what factors can explain the differential impact of these two laws? One hypothesis is that the higher-income families eligible for coverage under the 133 percent expansion have a relatively low probability of remaining Medicaid-eligible in the near future, and are therefore less willing to undertake a lengthy enrollment process than families with a higher probability of continuing eligibility. To evaluate this hypothesis, we used the 1992 and 1993 SIPP panels to calculate Medicaid eligibility status 12 months after the first interview for children in different eligibility groups at the first interview. The results are presented in Table 8. Among all children who were Medicaid-eligible at the first interview, 78 percent were eligible 12 months later. As expected, the rate of future eligibility is highest for the poorest children (who are eligible via AFDC at the first interview), somewhat lower for those eligible under both the 100 percent and 133 percent expansions, and 
lowest for those eligible under the 133 percent expansions only. ${ }^{31}$ Nevertheless, over 60 percent of the 133-percent-only group are eligible a year later. By comparison, the rate of future eligibility is only 21 percent for children who are ineligible for Medicaid at the first interview but have family incomes under $166 \%$ of poverty. Qualitatively, future eligibility rates are lower for families covered by the 133 percent expansion than for families covered by the 100 percent expansion. Quantitatively, however, the difference is small.

Another hypothesis is that the higher income families affected by the 133 percent expansion have less experience with means-tested benefit programs and therefore have less information about such programs, or perhaps attach greater stigma to participating in the them. Comparisons of the characteristics of the children and families in the different eligibility groups in Table 8 suggest there may be some truth to this idea. For example, families in the 133percent-only eligibility group are much less likely to be female-headed or black than families in the 100-percent-only eligibility group: both characteristics are highly correlated with welfare participation rates. To test the hypothesis more formally, we took all children in the $16^{\text {th }}$ month of the 1992 and 1993 SIPP panels, and calculated their Medicaid eligibility status. We then compared rates of AFDC and Medicaid participation 12 months earlier across different eligibility groups. The results, presented in Table 9, confirm that families of children in the 133-percentonly eligibility group have lower rates of previous participation in welfare or Medicaid than

${ }^{31}$ If income for family $i$ in month $\mathrm{t}$ follows a simple mean-regressive process like: $y_{i t}=\alpha_{i}$ $+u_{i t}$, where $u_{i t}=\rho u_{i t-1}+\epsilon_{i t}$ is a first order autoregressive process with $\rho>0$ and $\epsilon_{i t}$ is i.i.d. , then it is easy to show that $\mathrm{P}\left(\mathrm{y}_{\mathrm{it}+\mathrm{k}} \leq \mathrm{M} \mid \mathrm{y}_{\mathrm{it}} \leq \mathrm{L}\right)>\mathrm{P}\left(\mathrm{y}_{\mathrm{it+k}} \leq \mathrm{M} \mid \mathrm{L}<\mathrm{y}_{\mathrm{it}} \leq \mathrm{M}\right)$. Thus, families whose incomes fall below the poverty line (L) in month $t$ are more likely to have income below the Medicaid limit (M) k months later than those with incomes between the poverty line and the Medicaid limit in month $\mathrm{t}$. 
families of children who are eligible under AFDC or the 100 percent expansion. The differences in previous program participation rates are somewhat larger than the differences in future eligibility rates in Table 8 . For example, 45 percent of children in the 100-percent-only eligibility group were on Medicaid one year earlier, compared with 29 percent of the 133percent-only group. To the extent that previous program participation increases knowledge about Medicaid, or reduces the stigma associated with entering the program, these gaps could help to explain the lower takeup rate by children in the 100-percent-only eligibility group than in the 133-percent-only group.

\section{Conclusions}

This paper presents new estimates of the effects of the federal Medicaid expansions in the early 1990s, using comparisons of children close to the eligibility limits of the laws. We find that the 100 percent expansion - which extended Medicaid eligibility to children born after September 30, 1983 in families below the poverty line - led to about a 10 percentage point rise in Medicaid coverage for children just inside the eligibility limits, and a similar or slightly smaller rise in overall health insurance. It also increased the fraction of children in the newly eligible group with a doctor visit in the previous year. The impacts of the expansion on Medicaid coverage are discernable from a simple graphical analysis, in conventional differences-indifferences, and in a regression-discontinuity framework. Nevertheless, the takeup rate in the newly eligible population was low - on the order of 10 percent. The 133 percent expansion which opened up Medicaid to children under 6 in families with incomes below 133 percent of the poverty line - had even smaller impacts. We find no effect of the 133 percent expansion on 
Medicaid coverage rates of children close to the eligibility limits of the law in the SIPP or CPS. Even in the HIS, which shows a small effect on Medicaid, there is no effect on overall health insurance coverage.

Our findings underscore the conclusion of earlier research that the impact of recent Medicaid expansions was limited by low takeup rates among the newly eligible children. Indeed, our estimated takeup rates for children near the age boundaries of the federal laws are even lower than suggested by previous studies. An examination of eligibility dynamics in the SIPP suggests that the newly eligible children under the recent expansions differ from traditional Medicaid participants in two key dimensions. Families of the newly eligible children - especially those covered by the 133 percent expansion - have less previous contact with means-tested programs. As a result, they may have less information about Medicaid, or may feel greater stigma from participating in the program, than the traditional Medicaid clientele. The newly-eligible children are also less likely to remain eligible in the near future. Consequently, their families may be less willing to go through a lengthy enrollment process. Whatever the explanation for the low takeup, the behavior of children affected by the 100 percent and 133 percent expansions suggests that increases in the income limits for Medicaid eligibility have very limited effects on health insurance coverage of poor and near-poor children. To the extent that these patterns continue, the recent SCHIP programs will have only modest impacts. 


\section{References}

Angrist, Joshua D. and Alan B. Krueger. "Empirical Strategies in Labor Economics.” In Orley Ashenfelter and David Card, editors, Handbook of Labor Economics (Volume 3A). New York, Elsevier, 1999.

Bennefield, Robert L. "A Comparative Analysis of Health Insurance Coverage Estimates: Data from CPS and SIPP." Proceedings from the 1996 Joint Statistical Meetings, Social Science Section, 1996.

Card, David and Lara D. Shore-Sheppard. "Using Discontinuous Eligibility Rules to Identify the Effects of the Federal Medicaid Expansions." UC Berkeley Center for Labor Economics Working Paper No. 36, September 2001.

Card, David, Andrew Hildreth and Lara D. Shore-Sheppard. "The Measurement of Medicaid Coverage in the SIPP: Evidence from California, 1990-1996." UC Berkeley Center for Labor Economics Working Paper No. 32, February 2001.

Currie, Janet and Jonathan Gruber. "Health Insurance Eligibility, Utilization of Medical Care, and Child Health." Quarterly Journal of Economics 111 (1996), pp. 431-466.

Cutler, David M. and Jonathan Gruber. "Does Public Insurance Crowd out Private Insurance?" Quarterly Journal of Economics 111 (1996), pp. 391-430.

Dubay, Lisa C. and Genevieve Kenney. "The Effects of the Medicaid Expansions on Insurance Coverage of Children." The Future of Children 6 (1996), pp. 152-161.

Ham, John C. and Lara D. Shore-Sheppard. "The Effect of Medicaid Expansions for LowIncome Children on Medicaid Participation and Insurance Coverage: Evidence from the SIPP." NBER Working Paper No. 8063, January 2001.

Holl, J.L., P.G. Szilagy, L.E. Rodewald, R.S. Byrd, and M.D. Weitzman. "Profile of Uninsured Children in the United States." Archives of Pediatric and Adolescent Medicine 149 (1995), pp. 398-406.

Kaye, H. Stephen, Mitchell P. LaPlante, Dawn Carlson, and Barbara L. Wenger. "Trends in Disability Rates in the United States, 1970-1994." Disability Statistics Abstract 17 (1996). U.S. Department of Education, National Institute on Disability and Rehabilitation Research (November), pp. 1-6.

Kubik, Jeffrey D. "Incentives for the Identification and Treatment of Children with Disabilities: The Supplemental Security Income Program." Journal of Public Economics 73 (1999), pp. 187215. 
Moffitt, Robert A., Robert T. Reville, and Anne E. Winkler. "State AFDC Rules Regarding the Treatment of Cohabitors: 1993.” Social Security Bulletin 57 (1994), pp. 26-33.

National Governor's Association, Center for Best Practices, Health Policy Studies Division. "States have Expanded Eligibility Through Medicaid and the State Children's Health Insurance Program". Maternal and Child Health (MCH) Update (U.S. Department of Health and Human Services Health, Resources Administration, Maternal and Child Health Bureau). February 1999.

Nelson, Charles T. and Robert J. Mills. "The March CPS Health Insurance Verification Question and Its Effect on Estimates of the Uninsured." U.S. Census Bureau Unpublished Research Report, August 2001. (http://www.census.gov/hhes/hlthins/verif.html).

Pischke, Jorn-Steffen. "Individual Income, Incomplete Information, and Aggregate Consumption." Econometrica 63(4) July 1995, pp. 805-840.

Shore-Sheppard, Lara D. "The Effect of Expanding Medicaid Eligibility on the Distribution of Children's Health Insurance Coverage." Industrial and Labor Relations Review 54 (October 2000), pp. 59-77.

United States House of Representatives Committee on Ways and Means. Green Book: Background Material and Data on Programs Within the Jurisdiction of the Committee on Ways and Means. Washington, DC: U.S. Government Printing Office, 1986-1991.

Yazici, Ezel and Robert Kaestner. "Medicaid Expansions and the Crowding Out of Private Health Insurance Among Children.” Inquiry 37(1), Spring 2000, pp. 23-32. 
Data Appendix

\section{Surveys of Income and Program Participation}

Our SIPP samples are taken from the 1990-1993 full panel research files. The samples include individuals up to 18 years of age in the $4^{\text {th }}$ interview month who are neither the head of a family nor the spouse of a head. Individuals in 9 states that are not separately identified are dropped. We constructed nuclear families for the children in our sample using information on relationship to household head, family status, and relationship to family head. In most cases the re-constructed families correspond to the members of the SIPP households. In cases where a child and his or her parent(s) live with other adults, however, our families include only the children and parent(s) of the appropriate subfamily. This definition corresponds to the family benefit unit that would be potentially eligible for AFDC or Medicaid. Variables such as family income and family structure are then calculated by summing the individual values for people in the family. We also assign family-specific poverty thresholds based on family size and year.

To determine the maximum income cutoff for AFDC, we merge AFDC benefit levels and need standards to individuals, based on state of residence and family size. There are two income tests that a family must pass in order to qualify for AFDC - the "gross test", which requires that a family's gross income be less than 1.85 times the state's need standard, and the "net test", which requires that a family's income after disregards be less than the state's payment standard. In determining AFDC eligibility, families are permitted to disregard actual child care expenses up to a maximum of $\$ 175$ per month ( $\$ 200$ per month for children under 2$)$. Since we do not know actual child care expenses, we assume that families can deduct the full disregard for all children under age 6, and no disregard for older children. This assumption overstates the amount of the disregard for families that use informal or low cost care. Income eligibility cutoffs for Medicaid are determined using the age of the child, the ratio of family income to the family-specific poverty line, and the parameters of the relevant state Medicaid programs.

\section{Current Population Surveys}

We use data for individuals 18 and younger who are neither the head of a family nor the spouse of a head from the 1989-1999 March Current Population Surveys. Since subfamilies are identified directly in the CPS, we use subfamily income and poverty levels to assign income relative to the family poverty level. Income eligibility cutoffs for AFDC and Medicaid are determined as in the SIPP. We use information on health insurance coverage from the individual responses and the children's recoded variables to assign Medicaid and other insurance coverage.

\section{Health Interview Surveys}

We use data for individuals age 18 or younger who are neither the head nor the spouse of a head in the 1992-1996 Health Interview Surveys. We exclude observations with missing family income, Medicaid coverage, parental status, or birth month/year. We assign midpoint values to the HIS categorical annual family income variable, and we use information on the number of individuals in the family to assign approximate family poverty lines. We assign Medicaid coverage to individuals who report that they are covered by Medicaid or other public 
assistance health insurance programs. We assign overall coverage if an individual has Medicaid, private health insurance, or military coverage. 
Appendix Table 1: Summary of Federal Legislation Related to Medicaid Coverage for Pregnant Women, Infants, and Children, 1986-1990.

\section{Omnibus Budget Reconciliation Act (OBRA) 1986. Effective: April 1987.}

Optional: States may raise the income eligibility threshold above AFDC levels to as high as the Federal poverty level for pregnant women, infants, and children up to 5 years of age, even if the principal earner is employed. (Children may be phased in gradually.)

\section{Omnibus Budget Reconciliation Act (OBRA) 1987. Effective: July 1988.}

Required: States must cover all children under age 7 born after 9/30/83 who meet income and resource standards for AFDC, regardless of family structure.

Optional: States may raise income thresholds for pregnant women and infants to $185 \%$ of the Federal poverty level. States may cover children under age 2,3,4, or 5 who were born after 9/30/83 with incomes below the Federal poverty level.

\section{Medicare Catastrophic Coverage Act (MCCA). Effective: July 1989.}

Required: States must cover pregnant women and infants with incomes less than or equal to $75 \%$ of the poverty level (it was to move to $100 \%$ by the following year, but was superseded by OBRA 1989)

Optional: States may cover children up to 8 years of age with incomes less than or equal to $75 \%$ of the poverty level.

\section{Family Support Act (FSA) 1988. Effective: October 1990.}

Required: States must extend Medicaid coverage to eligible 2-parent families where the principal earner is unemployed.

\section{Omnibus Budget Reconciliation Act (OBRA) 1989. Effective: April 1990.}

Required: States must cover pregnant women and children under age 6 with family incomes up to 133\% of the Federal poverty level.

\section{Omnibus Budget Reconciliation Act (OBRA) 1990. Effective: July 1991}

Required: States must cover children under age 19 who were born after 9/30/83 whose family income level is below $100 \%$ of the poverty level. States must continue benefits for pregnant women until 2 months after the end of pregnancy, and for infants through the first year of life. 
Appendix Table 2: Characteristics of Children in 1992-93 SIPP, March CPS, and HIS

\begin{tabular}{|c|c|c|c|c|}
\hline & \multirow[b]{2}{*}{ SIPP } & \multirow{2}{*}{$\begin{array}{c}\text { March } \\
\text { CPS }\end{array}$} & \multicolumn{2}{|r|}{ HIS : } \\
\hline & & & All & with Income \\
\hline Percent Age $0-5$ Years & 33.3 & 34.3 & 33.7 & 34.0 \\
\hline Percent Born After 9/30/1983 & 49.1 & -- & 50.7 & 51.2 \\
\hline Percent Black & 16.7 & 15.1 & 15.8 & 14.8 \\
\hline Percent Hispanic & 13.8 & 11.5 & 13.0 & 12.8 \\
\hline Percent with Single Mother & 24.4 & 23.9 & 16.1 & 16.1 \\
\hline Percent Below Pov. Line & 24.9 & 23.9 & 22.0 & 22.0 \\
\hline Percent 100-200\% Pov. Line & 22.9 & 21.4 & 26.7 & 26.7 \\
\hline Percent on AFDC & 11.0 & 12.8 & -- & -- \\
\hline Percent on Medicaid & 18.0 & 20.0 & 17.3 & 17.1 \\
\hline Percent on Medicaid not AFDC & 7.0 & 7.4 & -- & -- \\
\hline Percent with Health Insurance & 85.8 & 85.8 & 81.9 & 84.0 \\
\hline Number Observations & 28,557 & 86,171 & 52,796 & 45,000 \\
\hline $\begin{array}{l}\text { Notes: Sample includes indivic } \\
1993 \text { SIPP panel, the } 1991 \text { and } \\
\text { Health Interview Surveys. SIP } \\
\text { Vermont, Iowa, North Dakota, } \\
\text { Wyoming. HIS sample excludes } \\
\text { information. All means are we }\end{array}$ & $\begin{array}{l}\text { duals age } \\
1992 \text { Mar } \\
\text { PP sample } \\
\text { South Dak } \\
\text { observat } \\
\text { eighted. }\end{array}$ & $\begin{array}{l}0-18 \text { in } \\
\text { ch CPS, a } \\
\text { excludes } \\
\text { ota, Alas } \\
\text { ions with }\end{array}$ & $\begin{array}{l}\text { ve } 1 \text { of } \\
\text { the } 199 \\
\text { bservati } \\
\text { Idaho, } \\
\text { issing b }\end{array}$ & $\begin{array}{l}\text { he } 1992 \text { and } \\
\text { and } 1993 \\
\text { Mo in Maine, } \\
\text { Montana, } \\
\text { rth date }\end{array}$ \\
\hline
\end{tabular}


Appendix Table 3: Comparisons of Medicaid Eligibility and Participation Rates for Children Older and Younger than Age 6 in Families Above and Below 133\% of the Poverty Line, Current Population Survey 1991-1996

\begin{tabular}{|c|c|c|c|c|c|c|}
\hline CPS Year & $\begin{array}{l}\text { Percent } \\
\text { Medicaid } \\
\text { Eligible }\end{array}$ & $\begin{array}{l}\text { Percent } \\
\text { Covered by } \\
\text { Medicaid }\end{array}$ & $\begin{array}{l}\text { Percent } \\
\text { on AFDC }\end{array}$ & $\begin{array}{c}\text { Percent on } \\
\text { Medicaid } \\
\text { not AFDC }\end{array}$ & $\begin{array}{l}\text { Percent } \\
\text { with Any } \\
\text { Insurance }\end{array}$ & $\begin{array}{l}\text { Percent } \\
\text { with Other } \\
\text { Insurance } \\
\end{array}$ \\
\hline 1991 & $\begin{array}{l}94.1 \\
(0.6)\end{array}$ & $\begin{array}{c}2.3 \\
(2.1)\end{array}$ & $\begin{array}{l}-3.0 \\
(1.6)\end{array}$ & $\begin{array}{c}4.9 \\
(1.6)\end{array}$ & $\begin{array}{l}-2.6 \\
(2.4)\end{array}$ & $\begin{array}{l}-8.8 \\
(2.6)\end{array}$ \\
\hline 1992 & $\begin{array}{l}85.8 \\
(1.0)\end{array}$ & $\begin{array}{l}-0.2 \\
(2.2)\end{array}$ & $\begin{array}{l}-0.5 \\
(1.7)\end{array}$ & $\begin{array}{c}0.4 \\
(1.8)\end{array}$ & $\begin{array}{c}1.2 \\
(2.4)\end{array}$ & $\begin{array}{c}1.7 \\
(2.7)\end{array}$ \\
\hline 1993 & $\begin{array}{l}77.0 \\
(1.4)\end{array}$ & $\begin{array}{c}3.6 \\
(2.2)\end{array}$ & $\begin{array}{c}4.8 \\
(1.6)\end{array}$ & $\begin{array}{c}-1 \cdot 3 \\
(1.9)\end{array}$ & $\begin{array}{l}-1 \cdot 7 \\
(2.3)\end{array}$ & $\begin{array}{l}-4.0 \\
(2.6)\end{array}$ \\
\hline 1994 & $\begin{array}{l}64.8 \\
(1.5)\end{array}$ & $\begin{array}{c}1.0 \\
(2.3)\end{array}$ & $\begin{array}{c}0.5 \\
(1.6)\end{array}$ & $\begin{array}{c}1.1 \\
(2.0)\end{array}$ & $\begin{array}{c}1.1 \\
(2.2)\end{array}$ & $\begin{array}{l}-0.2 \\
(2.6)\end{array}$ \\
\hline 1995 & $\begin{array}{l}73.1 \\
(1.4)\end{array}$ & $\begin{array}{l}-1.1 \\
(2.4)\end{array}$ & $\begin{array}{c}0.9 \\
(1.7)\end{array}$ & $\begin{array}{l}-2.6 \\
(2.0)\end{array}$ & $\begin{array}{l}-0.1 \\
(2.3)\end{array}$ & $\begin{array}{c}1.6 \\
(2.6)\end{array}$ \\
\hline 1996 & $\begin{array}{l}82.8 \\
(1.0)\end{array}$ & $\begin{array}{c}0.7 \\
(2.5)\end{array}$ & $\begin{array}{c}-0.7 \\
(1.8)\end{array}$ & $\begin{array}{c}1.3 \\
(2.2)\end{array}$ & $\begin{array}{l}-0.8 \\
(2.4)\end{array}$ & $\begin{array}{l}-1.7 \\
(2.7)\end{array}$ \\
\hline
\end{tabular}

Note: Table entries are regression-adjusted differences in differences. See note to Table 6 for model specifications and sample definitions. 
Figure 1: Health Insurance Coverage Rates by Family Income in 1989, 1993, and 1999

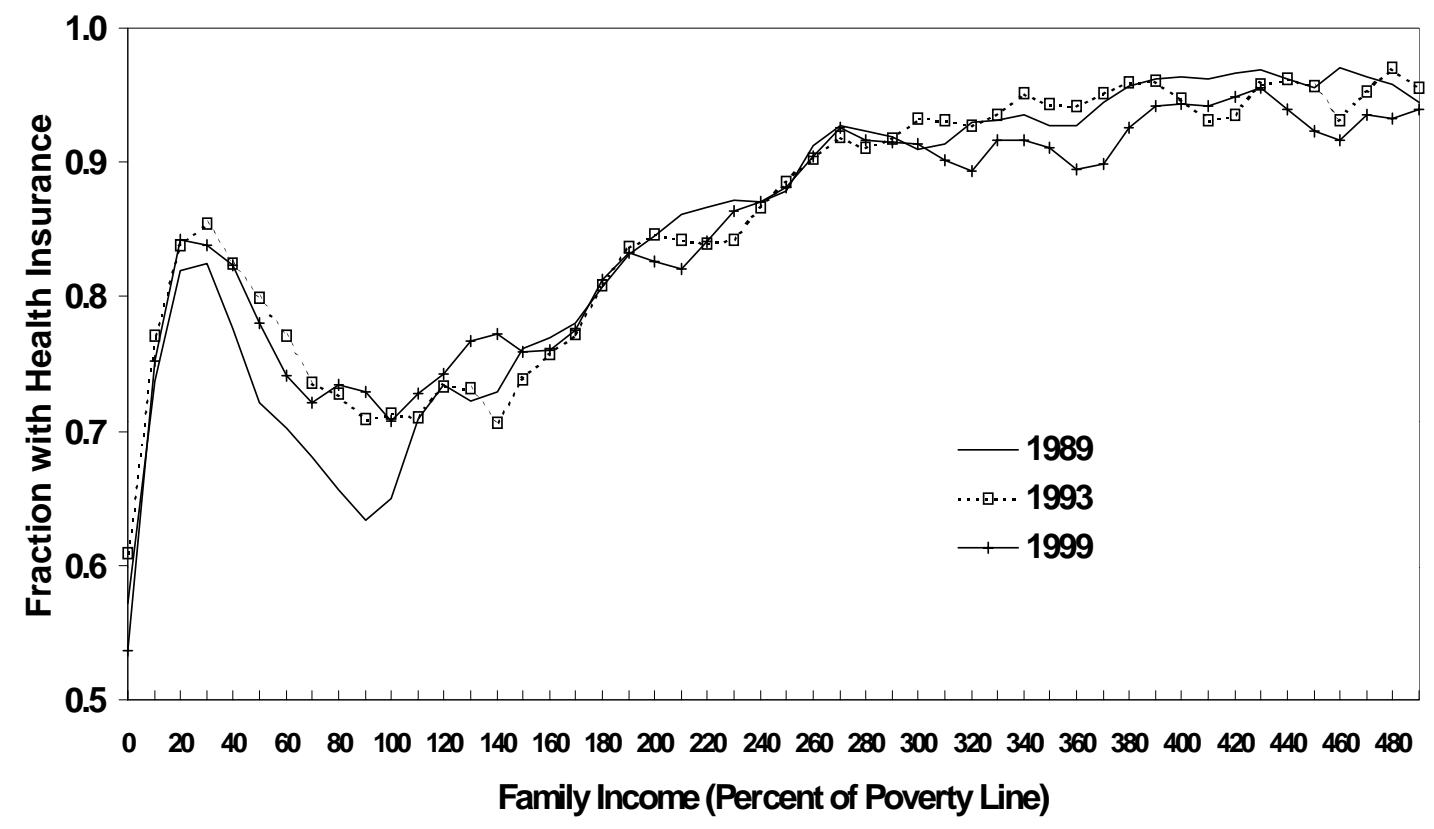


Figure 2: Medicaid Eligibility by Birth Quarter, Children in 1992-93 SIPP

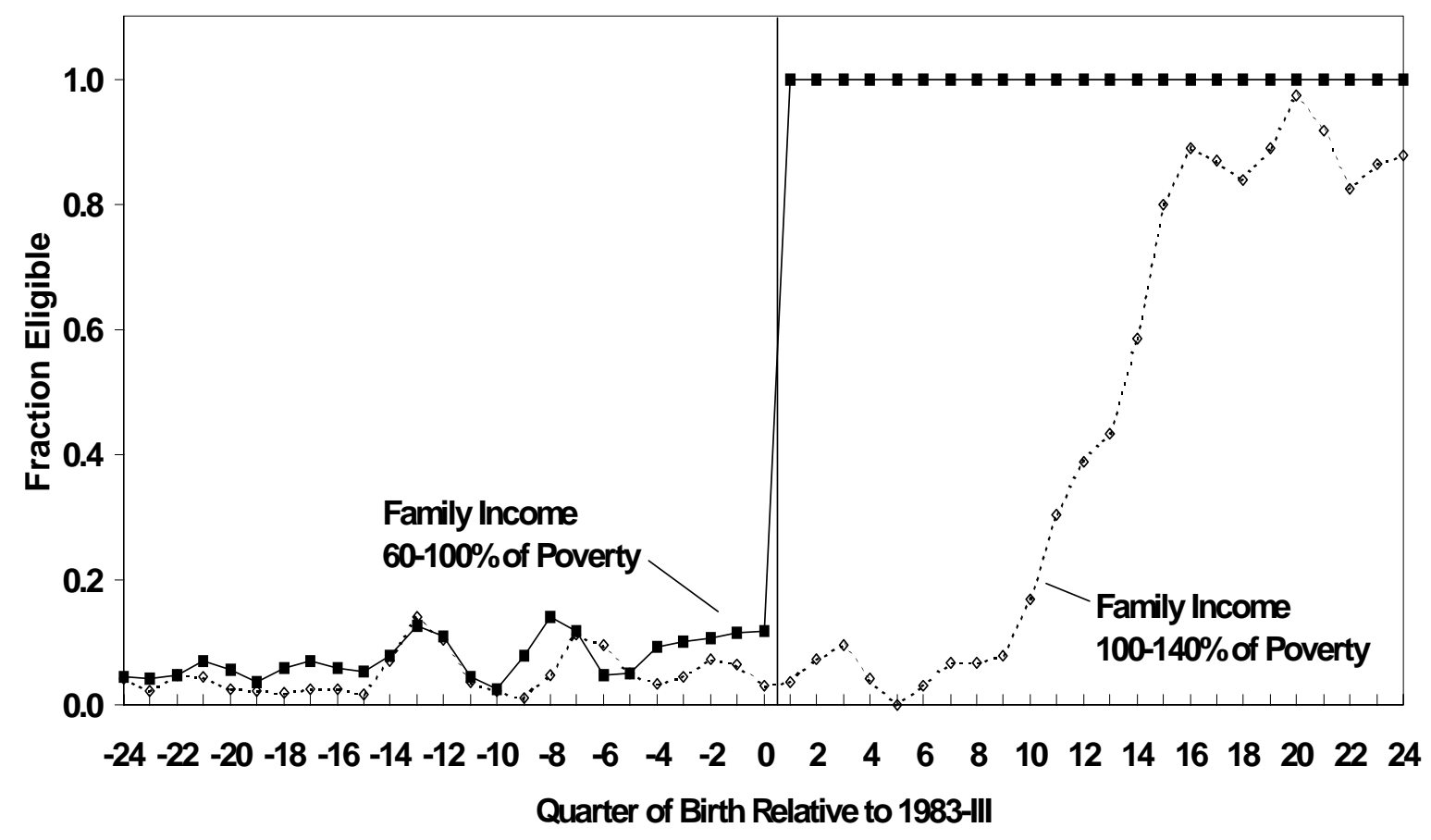


Figure 3: Medicaid Coverage Rate by Birth Quarter

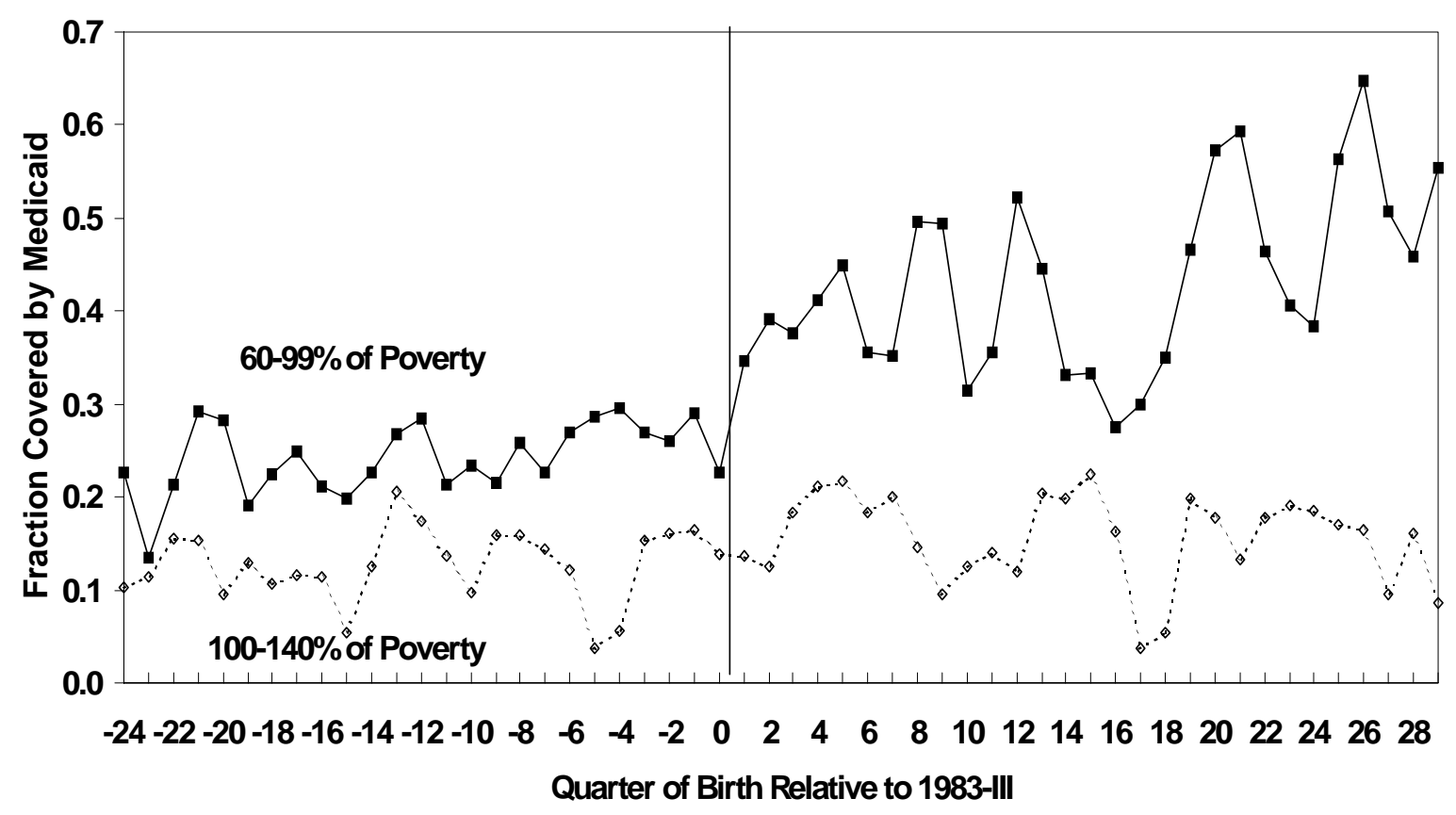


Figure 4: Medicaid Coverage Rates by Family Income

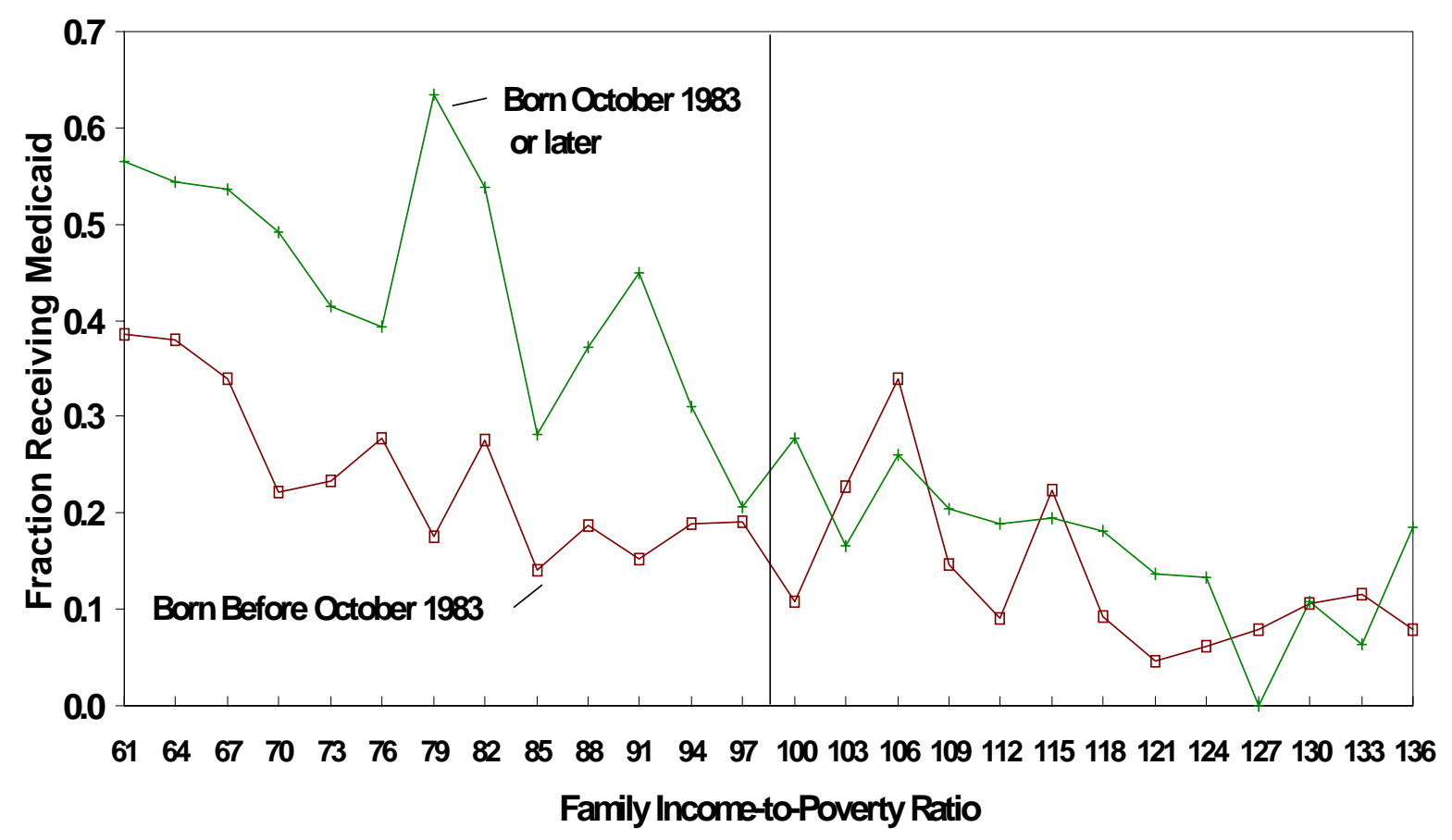


Figure 5: Medicaid Coverage Rates by Age

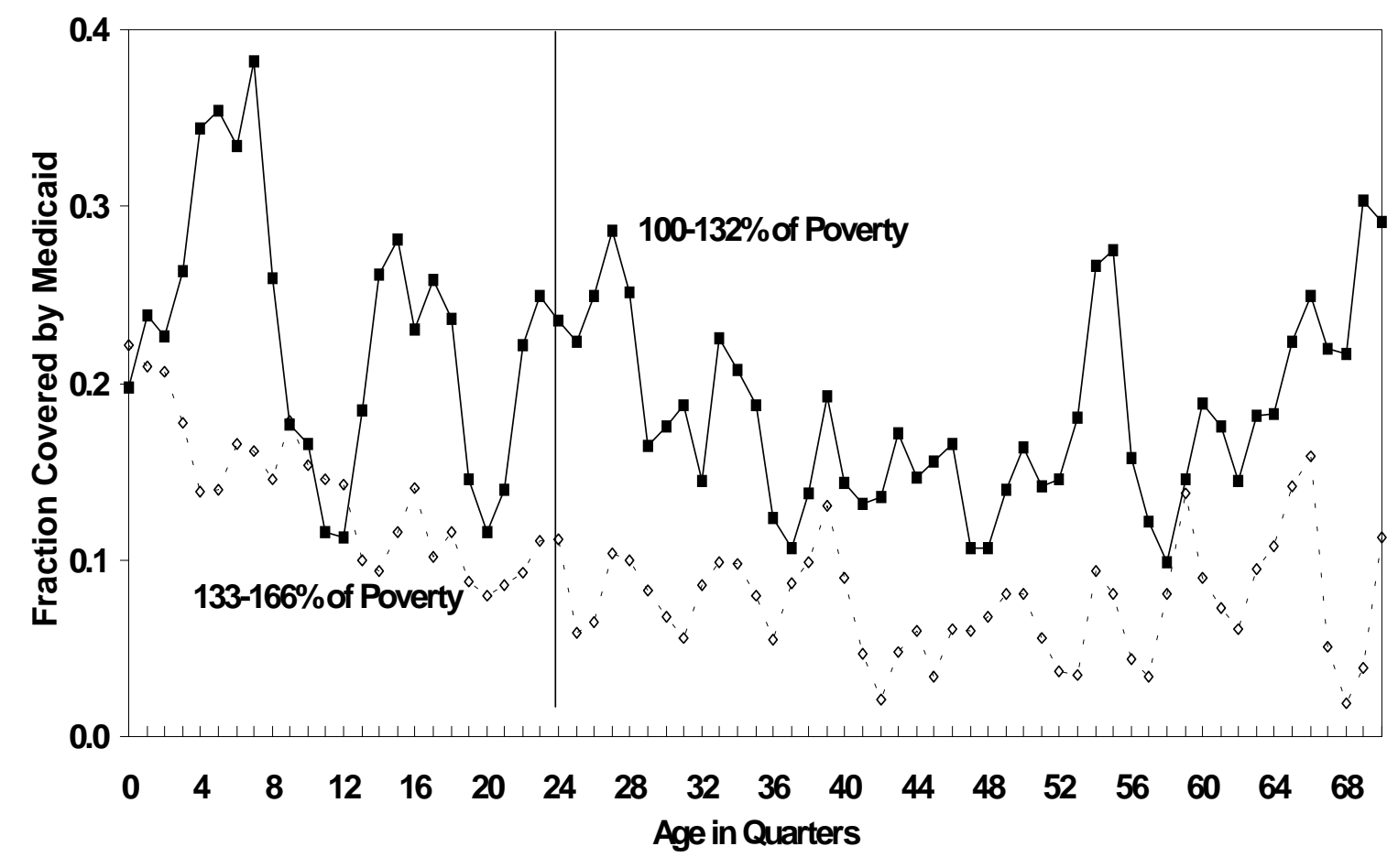


Figure 6: Medicaid Coverage Rates by Quarter of Birth, 1992-96 HS

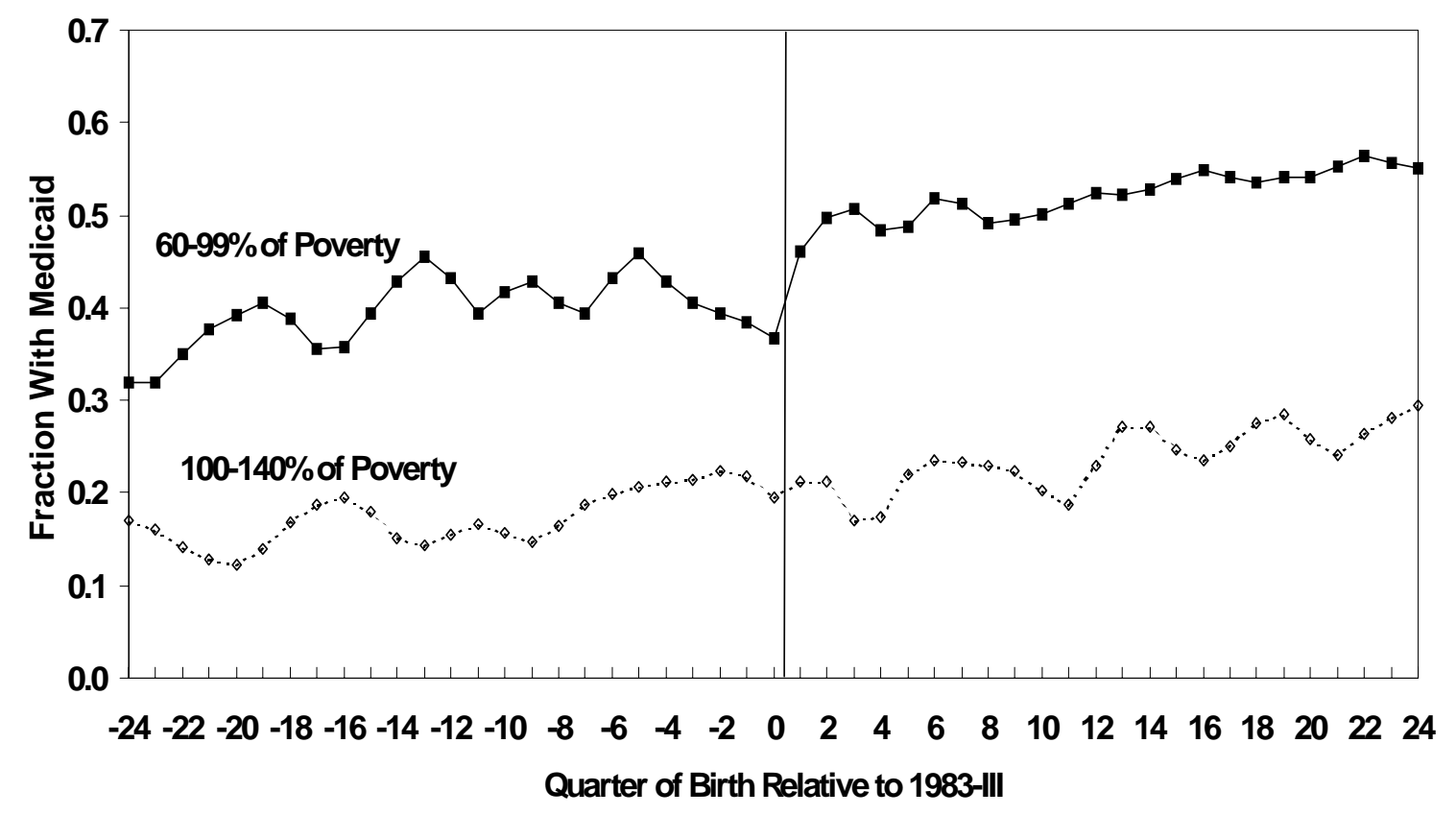


Table 1: Characteristics of Children in 1990-1993 SIPP Panels

\begin{tabular}{|c|c|c|c|c|}
\hline & 1990 & 1991 & 1992 & 1993 \\
\hline \multicolumn{5}{|l|}{ Age Distribution: } \\
\hline Percent Age 0-5 Years & 33.3 & 32.9 & 33.5 & 33.2 \\
\hline Percent Born After 9/30/1983 & 35.9 & 40.8 & 46.6 & 51.7 \\
\hline $\begin{array}{l}\text { Percent Born Afer } 9 / 30 / 1983 \\
\text { and Age } 6 \text { or Older }\end{array}$ & 2.5 & 7.9 & 13.1 & 18.4 \\
\hline \multicolumn{5}{|c|}{ Family Income Distribution Relative to Poverty Lir } \\
\hline Percent Below Pov. Line & 21.2 & 24.3 & 23.8 & 26.1 \\
\hline $\begin{array}{l}\text { Percent Between Poverty Line } \\
\text { and } 133 \% \text { of Poverty }\end{array}$ & 7.6 & 6.9 & 7.4 & 7.2 \\
\hline $\begin{array}{l}\text { Mean AFDC Income Cutoff } \\
\text { (Percent of Pov. Line) }\end{array}$ & 68.9 & 67.4 & 63.1 & 60.2 \\
\hline Percent Below AFDC Cutoff & 15.4 & 17.5 & 16.2 & 17.0 \\
\hline $\begin{array}{l}\text { Percent Between AFDC Cutoff } \\
\text { and Poverty Line }\end{array}$ & 6.1 & 6.9 & 7.8 & 9.1 \\
\hline \multicolumn{5}{|l|}{ Medicaid Eligibility: } \\
\hline $\begin{array}{l}\text { Mean Medicaid Income Cutoff } \\
\text { (Percent of Pov. Line) }\end{array}$ & 76.5 & 86.4 & 92.7 & 111.9 \\
\hline $\begin{array}{l}\text { Percent Eligible for Medicaid } \\
\text { not AFDC }\end{array}$ & 1.7 & 4.3 & 6.7 & 11.7 \\
\hline Percent Eligible for Medicaid & 17.1 & 21.8 & 22.9 & 28.7 \\
\hline $\begin{array}{l}\text { Percent of Eligibles with } \\
\text { Income Over AFDC Cutoff }\end{array}$ & 9.9 & 19.7 & 29.3 & 40.8 \\
\hline \multicolumn{5}{|l|}{ AFDC and Medicaid Participation: } \\
\hline Percent on AFDC & 8.4 & 9.9 & 10.0 & 12.0 \\
\hline Percent on Medicaid not AFDC & 3.7 & 5.7 & 6.2 & 7.7 \\
\hline Percent on Medicaid & 12.1 & 15.6 & 16.2 & 19.7 \\
\hline $\begin{array}{l}\text { Percent of Medicaid Recipients } \\
\text { Not on AFDC }\end{array}$ & 30.1 & 36.5 & 38.3 & 39.1 \\
\hline Number Observations & 16,196 & 10,268 & 14,063 & 14,494 \\
\hline
\end{tabular}

Notes: Sample includes individuals age 0-18 in wave 1 of the SIPP panels who are not heads of families. Characteristics are measured as of the fourth interview month. See text for description of AFDC and Medicaid income cutoffs. Means are weighted by first year weights. (All subsequent calculations use first year weights unless otherwise noted.) 
Table 2: Medicaid Eligibility Rates by Source of Eligibility, and Medicaid Participation Rates of Eligibility Groups

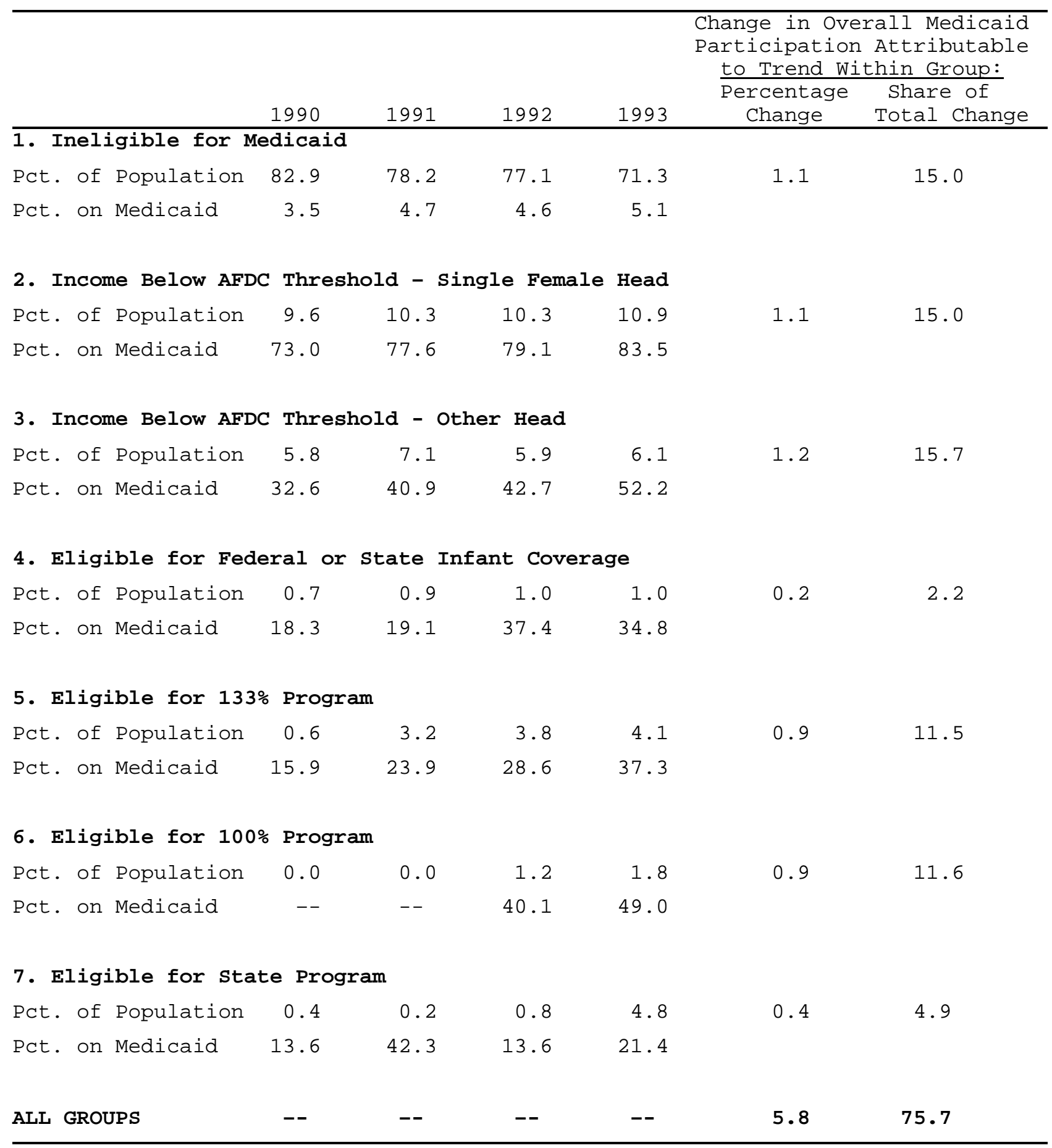

Notes: see notes to Table 1. Children who are eligible under several criteria are assigned to the first criterion they meet. Entry in column 5 is the change in Medicaid participation for the group, multiplied by the group's population share in 1993. Entry in column 6 is the entry in column 5, divided by total rise in Medicaid participation (7.6\%). 
Table 3: Medicaid Eligibility and Program Participation for Children Eligible and Ineligible for 100 Percent Program

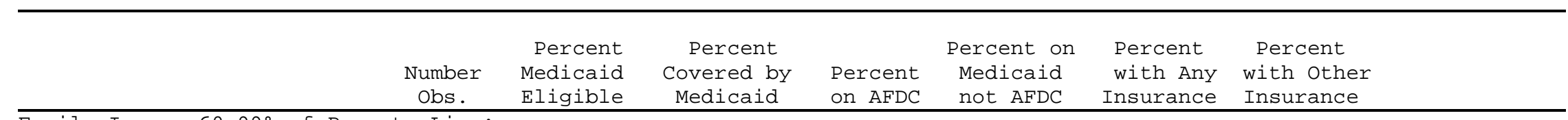

Family Income 60-99\% of Poverty Line:

$\begin{array}{lccccccc}\text { Born Before 10/1/83 } & 888 & 6.8 & 24.1 & 13.8 & 10.4 & 57.6 & 34.2 \\ & & (0.8) & (1.4) & (1.2) & (1.0) & (1.7) & (1.6) \\ \text { Born 10/1/83 or Later } & 278 & 100.0 & 40.1 & 15.1 & 25.1 & 69.5 & 32.1 \\ \text { and Age } 6 \text { or Older } & & (0.0) & (2.9) & (2.1) & (2.6) & (2.8) \\ \text { Born 10/1/83 or Later } & 639 & 100.0 & 44.8 & 11.5 & 33.3 & 72.3 & 31.8 \\ & & (0.0) & (2.0) & (1.3) & (1.9) & (1.8) & (1.8)\end{array}$

Family Income 100-140\% of Poverty Line:

$\begin{array}{lccccccc}\text { Born Before 10/1/83 } & 841 & 4.7 & 12.8 & 5.3 & 7.5 & 66.1 & 55.6 \\ & & (0.7) & (1.2) & (0.8) & (0.9) & (1.6) & (1.7) \\ \text { Born 10/1/83 or Later } & 278 & 5.9 & 17.0 & 3.9 & 13.1 & 65.3 & 52.1 \\ \text { and Age 6 or Older } & & (1.4) & (2.3) & (1.2) & (2.0) & (2.8) & (3.0) \\ \text { Born 10/1/83 or Later } & 670 & 50.8 & 17.8 & 2.7 & 15.2 & 70.5 & 55.7 \\ & & (1.9) & (1.5) & (0.6) & (1.4) & (1.8) & (1.9)\end{array}$

Comparison of Children Born Before and After 10/1/83 in Poor and Near-Poor Families:

\begin{tabular}{|c|c|c|c|c|c|c|c|}
\hline Difference-in-Differences & -- & $\begin{array}{l}92.0 \\
(2.2)\end{array}$ & $\begin{array}{l}11.8 \\
(4.0)\end{array}$ & $\begin{array}{l}2.7 \\
(2.9)\end{array}$ & $\begin{array}{c}9.2 \\
(3.1)\end{array}$ & $\begin{array}{l}12.6 \\
(4.8)\end{array}$ & $\begin{array}{l}1.3 \\
(4.8)\end{array}$ \\
\hline Regression-Adjusted D-in-D & -- & $\begin{array}{l}91.9 \\
(1.9)\end{array}$ & $\begin{array}{l}10.3 \\
(3.8)\end{array}$ & $\begin{array}{l}1.3 \\
(2.8)\end{array}$ & $\begin{array}{l}9.0 \\
(3.1)\end{array}$ & $\begin{array}{l}12.3 \\
(4.6)\end{array}$ & $\begin{array}{l}2.4 \\
(4.7)\end{array}$ \\
\hline $\begin{array}{l}\text { All Ages } \\
\text { Difference-in-Differences }\end{array}$ & -- & $\begin{array}{l}47.1 \\
(2.1)\end{array}$ & $\begin{array}{l}15.6 \\
(3.0)\end{array}$ & $\begin{array}{c}0.3 \\
(2.0)\end{array}$ & $\begin{array}{l}15.3 \\
(2.6)\end{array}$ & $\begin{array}{l}10.3 \\
(3.5)\end{array}$ & $\begin{array}{l}-2.6 \\
(3.6)\end{array}$ \\
\hline Regression-Adjusted D-in-D & -- & $\begin{array}{l}92.1 \\
(2.1)\end{array}$ & $\begin{array}{l}10.1 \\
(3.9)\end{array}$ & $\begin{array}{c}1.5 \\
(2.6)\end{array}$ & $\begin{array}{l}8.6 \\
(3.4)\end{array}$ & $\begin{array}{l}12.2 \\
(4.5)\end{array}$ & $\begin{array}{l}2.6 \\
(4.7)\end{array}$ \\
\hline
\end{tabular}

Notes: Standard errors in parentheses. Sample includes children in month 4 of 1992 and 1993 SIPP in families with incomes from 60-140\% of poverty line and with family-specific AFDC eligibility thresholds under 70\% of poverty line. Regression-adjusted difference-in-differences includes cubic in age (in months), dummy for age under 6 interacted with dummy for income below poverty, dummies for black, Hispanic, single mother, dummies for region interacted with survey year, ratio of family income to poverty line and its square, dummy if family income below poverty line, dummy if born after 10/1/83, and interaction of dummies for income below poverty line and born after 10/1/83 (reported in table). 
Table 4: Comparisons of Medicaid Eligibility and Program Participation Rates for Children Eligible and Ineligible for 133\% Program

\begin{tabular}{|c|c|c|c|c|c|c|c|}
\hline & $\begin{array}{l}\text { Number } \\
\text { Obs. }\end{array}$ & $\begin{array}{l}\text { Percent } \\
\text { Medicaid } \\
\text { Eligible }\end{array}$ & $\begin{array}{c}\text { Percent } \\
\text { Covered by } \\
\text { Medicaid }\end{array}$ & $\begin{array}{l}\text { Percent } \\
\text { on AFDC }\end{array}$ & $\begin{array}{l}\text { Percent on } \\
\text { Medicaid } \\
\text { not AFDC }\end{array}$ & $\begin{array}{l}\text { Percent } \\
\text { with Any } \\
\text { Insurance }\end{array}$ & $\begin{array}{l}\text { Percent } \\
\text { with Other } \\
\text { Insurance }\end{array}$ \\
\hline \multicolumn{8}{|c|}{ Family Income $100-132 \%$ of Poverty Line: } \\
\hline Age 6 and Older & 1552 & $\begin{array}{c}9.1 \\
(0.7)\end{array}$ & $\begin{array}{l}17.9 \\
(1.0)\end{array}$ & $\begin{array}{c}8.2 \\
(0.7)\end{array}$ & $\begin{array}{c}9.7 \\
(0.8)\end{array}$ & $\begin{array}{l}67.6 \\
(1.2)\end{array}$ & $\begin{array}{l}52.7 \\
(1.3)\end{array}$ \\
\hline Under Age 6 & 795 & $\begin{array}{r}100.0 \\
(0.0)\end{array}$ & $\begin{array}{l}22.5 \\
(1.5)\end{array}$ & $\begin{array}{c}4.5 \\
(0.7)\end{array}$ & $\begin{array}{l}18.0 \\
(1.4)\end{array}$ & $\begin{array}{l}77.1 \\
(1.5)\end{array}$ & $\begin{array}{l}58.2 \\
(1.7)\end{array}$ \\
\hline \multicolumn{8}{|c|}{ Family Income $134-166 \%$ of Poverty Line: } \\
\hline Age 6 and Older & 1710 & $\begin{array}{c}8.4 \\
(0.7)\end{array}$ & $\begin{array}{c}7.9 \\
(0.7)\end{array}$ & $\begin{array}{c}2.0 \\
(0.3)\end{array}$ & $\begin{array}{c}5.9 \\
(0.6)\end{array}$ & $\begin{array}{l}74.7 \\
(1.1)\end{array}$ & $\begin{array}{l}69.2 \\
(1.1)\end{array}$ \\
\hline Under Age 6 & 912 & $\begin{array}{l}15.3 \\
(1.2)\end{array}$ & $\begin{array}{l}13.4 \\
(1.1)\end{array}$ & $\begin{array}{c}1.9 \\
(0.5)\end{array}$ & $\begin{array}{l}11.5 \\
(1.1)\end{array}$ & $\begin{array}{l}84.6 \\
(1.2)\end{array}$ & $\begin{array}{l}74.1 \\
(1.5)\end{array}$ \\
\hline \multicolumn{8}{|c|}{ Comparisons of Children Under and Older than 6} \\
\hline Difference-in-Differences & -- & $\begin{array}{l}83.7 \\
(1.7)\end{array}$ & $\begin{array}{c}-0.8 \\
(2.1)\end{array}$ & $\begin{array}{l}-3.5 \\
(1.2)\end{array}$ & $\begin{array}{c}2.7 \\
(1.8)\end{array}$ & $\begin{array}{l}-0.5 \\
(2.6)\end{array}$ & $\begin{array}{c}0.6 \\
(2.9)\end{array}$ \\
\hline Regression-Adjusted D-in-D & -- & $\begin{array}{l}85.5 \\
(1.4)\end{array}$ & $\begin{array}{c}0.2 \\
(2.1)\end{array}$ & $\begin{array}{l}-3.1 \\
(1.2)\end{array}$ & $\begin{array}{c}3.2 \\
(1.8)\end{array}$ & $\begin{array}{c}-0.1 \\
(2.6)\end{array}$ & $\begin{array}{c}0.0 \\
(2.8)\end{array}$ \\
\hline $\begin{array}{l}\text { Regression-Adjusted D-in-D } \\
1992 \text { and } 1993 \text { ONLY }\end{array}$ & -- & $\begin{array}{l}83.1 \\
(1.8)\end{array}$ & $\begin{array}{l}-3.1 \\
(2.4)\end{array}$ & $\begin{array}{l}-3.0 \\
(1.4)\end{array}$ & $\begin{array}{l}-0.1 \\
(2.1)\end{array}$ & $\begin{array}{c}0.5 \\
(3.0)\end{array}$ & $\begin{array}{c}3.7 \\
(3.3)\end{array}$ \\
\hline
\end{tabular}

Notes: Standard errors in parentheses. Sample includes children in month 4 of 1991-1993 SIPP in families with incomes from 100-166\% of poverty line and with family-specific AFDC eligibility thresholds under 100\% of poverty line.

Regression-adjusted difference-in-differences includes age in months and dummy for age under 6 , dummies for black,

Hispanic, single mother, Census region interacted with sample year, ratio of family income to poverty line and its square, dummy if family income is below 133\% of poverty line, dummy if under age 6 , and interaction of dummies for income below $133 \%$ of poverty line and under age 6 (reported in table). 
Table 5: Combined Models for Medicaid Eligibility and Program Participation Rates for Children in Families with Incomes from 60 to 166 Percent of Poverty, 1992 and 1993 SIPP

\begin{tabular}{|c|c|c|c|c|c|c|}
\hline & $\begin{array}{l}\text { Medicaid } \\
\text { Eligible }\end{array}$ & $\begin{array}{l}\text { Covered by } \\
\text { Medicaid } \\
\end{array}$ & On AFDC & $\begin{array}{l}\text { On } \\
\text { Medicaid } \\
\text { not AFDC }\end{array}$ & $\begin{array}{l}\text { Have Any } \\
\text { Insurance }\end{array}$ & $\begin{array}{l}\text { Have } \\
\text { Other } \\
\text { Insurance }\end{array}$ \\
\hline $\begin{array}{l}\text { Eligible for } 100 \% \text { Program } \\
\text { ONLY }\left(c_{1}\right)\end{array}$ & $\begin{array}{l}66.8 \\
(2.0)\end{array}$ & $\begin{array}{l}9.5 \\
(2.9)\end{array}$ & $\begin{array}{l}0.6 \\
(2.1)\end{array}$ & $\begin{array}{l}9.0 \\
(2.5)\end{array}$ & $\begin{array}{l}9.7 \\
(3.2)\end{array}$ & $\begin{array}{l}1.3 \\
(3.4)\end{array}$ \\
\hline $\begin{array}{l}\text { Eligible for Both } 100 \% \\
\text { and 133\% Programs }\left(\mathrm{c}_{2}\right)\end{array}$ & $\begin{array}{l}67.8 \\
(1.8)\end{array}$ & $\begin{array}{l}9.8 \\
(2.7)\end{array}$ & $\begin{array}{l}-1.4 \\
(1.9)\end{array}$ & $\begin{array}{l}11.3 \\
(3.3)\end{array}$ & $\begin{array}{l}5.1 \\
(3.0)\end{array}$ & $\begin{array}{l}-2.4 \\
(3.1)\end{array}$ \\
\hline $\begin{array}{l}\text { Eligible for 133\% Program } \\
\text { ONLY }\left(\mathrm{C}_{3}\right)\end{array}$ & $\begin{array}{l}82.9 \\
(1.9)\end{array}$ & $\begin{array}{l}-3.0 \\
(2.8)\end{array}$ & $\begin{array}{l}-2.3 \\
(2.0)\end{array}$ & $\begin{array}{l}-0.7 \\
(2.4)\end{array}$ & $\begin{array}{l}1.1 \\
(3.1)\end{array}$ & $\begin{array}{l}4.1 \\
(3.2)\end{array}$ \\
\hline $\begin{array}{l}\text { P-value of Test: } \\
\mathrm{C}_{1}=\mathrm{C}_{2} \text { and } \mathrm{C}_{3}=0 .\end{array}$ & 0.00 & 0.73 & 0.73 & 0.85 & 0.58 & 0.40 \\
\hline
\end{tabular}

Notes: Standard errors in parentheses. Models are fit to sample of 6,045 children in 1992 and 1993 SIPP with family incomes from 60 to $166 \%$ of the poverty line. All models include cubic in age (in months), dummy for age under 6 , dummy if born after 10/1/83, dummy if family income below poverty, dummy if family income below 133\% of poverty, dummies for black, Hispanic, and single mother, dummies for Census region interacted with survey year, ratio of family income to poverty line and its square, and the three dummies reported in the table. 
Table 6: Comparisons of Medicaid Eligibility and Participation Rates for Children Older and Younger than Age 6 in Families Above and Below 133\% of the Poverty Line, Current Population Survey

\begin{tabular}{|c|c|c|c|c|c|c|c|}
\hline & $\begin{array}{l}\text { Number } \\
\text { Obs. }\end{array}$ & $\begin{array}{l}\text { Percent } \\
\text { Medicaid } \\
\text { Eligible }\end{array}$ & $\begin{array}{c}\text { Percent } \\
\text { Covered by } \\
\text { Medicaid } \\
\end{array}$ & $\begin{array}{l}\text { Percent } \\
\text { on AFDC }\end{array}$ & $\begin{array}{c}\text { Percent on } \\
\text { Medicaid } \\
\text { not AFDC }\end{array}$ & $\begin{array}{l}\text { Percent } \\
\text { with Any } \\
\text { Insurance }\end{array}$ & $\begin{array}{l}\text { Percent } \\
\text { with Other } \\
\text { Insurance }\end{array}$ \\
\hline \multicolumn{8}{|c|}{ Family Income $100-132 \%$ of Poverty Line: } \\
\hline Age 6 and Older & 6383 & $\begin{array}{c}7.7 \\
(0.3)\end{array}$ & $\begin{array}{l}23.9 \\
(0.5)\end{array}$ & $\begin{array}{l}13.9 \\
(0.4)\end{array}$ & $\begin{array}{l}11.1 \\
(0.4)\end{array}$ & $\begin{array}{l}71.8 \\
(0.6)\end{array}$ & $\begin{array}{l}54.3 \\
(0.6)\end{array}$ \\
\hline Under Age 6 & 2730 & $\begin{array}{l}100.0 \\
(0.0)\end{array}$ & $\begin{array}{l}33.2 \\
(0.9)\end{array}$ & $\begin{array}{l}14.8 \\
(0.7)\end{array}$ & $\begin{array}{l}18.5 \\
(0.7)\end{array}$ & $\begin{array}{l}77.8 \\
(0.8)\end{array}$ & $\begin{array}{l}54.3 \\
(1.0)\end{array}$ \\
\hline \multicolumn{8}{|c|}{ Family Income $134-166 \%$ of Poverty Line: } \\
\hline Age 6 and Older & 6334 & $\begin{array}{c}7.3 \\
(0.3)\end{array}$ & $\begin{array}{l}12.7 \\
(0.4)\end{array}$ & $\begin{array}{c}6.0 \\
(0.3)\end{array}$ & $\begin{array}{c}7.5 \\
(0.3)\end{array}$ & $\begin{array}{l}74.6 \\
(0.5)\end{array}$ & $\begin{array}{l}66.3 \\
(0.6)\end{array}$ \\
\hline Under Age 6 & 2788 & $\begin{array}{l}13.9 \\
(0.7)\end{array}$ & $\begin{array}{l}20.2 \\
(0.8)\end{array}$ & $\begin{array}{c}7.1 \\
(0.5)\end{array}$ & $\begin{array}{l}13.3 \\
(0.6)\end{array}$ & $\begin{array}{l}82.1 \\
(0.7)\end{array}$ & $\begin{array}{l}70.2 \\
(0.9)\end{array}$ \\
\hline Comparisons of Children Under & and Older & than 6 in & Families Ab & ve and $\mathrm{Be}$ & low $133 \%$ Pove & erty Limit & \\
\hline Difference-in-Differences & -- & $\begin{array}{l}85.7 \\
(0.8)\end{array}$ & $\begin{array}{c}1.8 \\
(1.4)\end{array}$ & $\begin{array}{l}-0.2 \\
(1.0)\end{array}$ & $\begin{array}{c}1.6 \\
(1.0)\end{array}$ & $\begin{array}{l}-1 \cdot 5 \\
(1 \cdot 3)\end{array}$ & $\begin{array}{l}-3.9 \\
(1.6)\end{array}$ \\
\hline Regression-Adjusted D-in-D & -- & $\begin{array}{l}85.4 \\
(0.6)\end{array}$ & $\begin{array}{c}2.2 \\
(1.3)\end{array}$ & $\begin{array}{c}0.4 \\
(0.9)\end{array}$ & $\begin{array}{c}1.5 \\
(1.0)\end{array}$ & $\begin{array}{l}-1 \cdot 1 \\
(1.4)\end{array}$ & $\begin{array}{l}-3.9 \\
(1.5)\end{array}$ \\
\hline
\end{tabular}

Notes: Standard errors in parentheses. Sample includes children in 1990-1993 March CPS in families with incomes from 100-166\% of poverty line and with family-specific AFDC eligibility thresholds under 100\% of poverty line. Regression-adjusted difference-in-differences includes age in years, dummy for age under 6 , dummies for black, Hispanic, single mother, dummies for Census region interacted with cPS year, ratio of family income to poverty line and its square, dummy if family income below 133\% of poverty line, dummy if under age 6, and interaction of dummies for income below 133\% of poverty line and under age 6 (reported in table). 
Table 7: Health Insurance Coverage and Probability of At Least One Doctor Visit in 1992-1996 Health Interview Surveys

\begin{tabular}{|c|c|c|c|}
\hline & & $\begin{array}{l}\text { Covered by } \\
\text { Medicaid }\end{array}$ & $\begin{array}{l}\text { At Least One } \\
\text { Doctor Visit } \\
\text { in Past Year }\end{array}$ \\
\hline \multicolumn{4}{|c|}{$\begin{array}{l}\text { A. Analysis of } 100 \% \text { Program Only: Children in Families } \\
\text { with Incomes from } 60-140 \% \text { of Poverty }(n=24,964)\end{array}$} \\
\hline (a) & $\begin{array}{l}\text { Unadjusted Difference } \\
\text { in Differences }\end{array}$ & $\begin{array}{l}5.0 \\
(1.2)\end{array}$ & $\begin{array}{l}1.8 \\
(1.1)\end{array}$ \\
\hline (a) & $\begin{array}{l}\text { Regression-Adjusted } \\
\text { D-in-D }\end{array}$ & $\begin{array}{c}4.8 \\
(1.5)\end{array}$ & $\begin{array}{l}2.9 \\
(1.3)\end{array}$ \\
\hline \multicolumn{4}{|c|}{$\begin{array}{l}\text { B. Analysis of } 100 \% \text { and } 133 \% \text { Programs: Children in Families } \\
\text { with Incomes from 60-166\% of Poverty }(n=32,617)\end{array}$} \\
\hline (c) & $\begin{array}{l}\text { Eligible for } 100 \% \\
\text { Program Only }\end{array}$ & $\begin{array}{l}8.0 \\
(1.2)\end{array}$ & $\begin{array}{l}3.8 \\
(1.2)\end{array}$ \\
\hline (d) & $\begin{array}{l}\text { Eligible for Both } 100 \% \\
\text { and 133\% Programs }\end{array}$ & $\begin{array}{l}9.6 \\
(1.3)\end{array}$ & $\begin{array}{l}1.6 \\
(1.2)\end{array}$ \\
\hline (e) & $\begin{array}{l}\text { Eligible for } 133 \% \\
\text { Program Only }\end{array}$ & $\begin{array}{c}5.8 \\
(1.2)\end{array}$ & $\begin{array}{c}0.5 \\
(1.2)\end{array}$ \\
\hline \multicolumn{4}{|c|}{$\begin{array}{l}\text { Notes: Standard errors in parentheses. Samples include children age 0-18 } \\
\text { in 1992-1996 Health Interview Surveys who report non-missing data on } \\
\text { family income, Medicaid coverage, and date of birth. Family-specific } \\
\text { poverty lines are assigned using family size information and midpoints of } \\
\text { reported family income categories. Specifications in Panel A are the } \\
\text { same as in Table 3. Specifications in Panel B are the same as in Table } \\
5 \text {. }\end{array}$} \\
\hline
\end{tabular}


Table 8: Comparisons of Subsequent Medicaid Eligibility for Children in 1992 and 1993 SIPP Who Were Medicaid-Eligible at the First Interview

\begin{tabular}{|c|c|c|c|c|c|}
\hline & $\begin{array}{l}\text { Charact } \\
\text { Female- } \\
\text { Headed } \\
\text { Family }\end{array}$ & ristics & at $1^{\text {st }}$ In & $\begin{array}{l}\text { Income / } \\
\text { Poverty }\end{array}$ & $\begin{array}{l}\text { Medicaid- } \\
\text { Eligible } \\
12 \text { Months } \\
\text { Later (\%) }\end{array}$ \\
\hline \multicolumn{6}{|l|}{$\begin{array}{l}\text { Basis of Eligibility } \\
\text { at First Interview: }\end{array}$} \\
\hline 1. All $(n=6,588)$ & 51.2 & 27.1 & 24.7 & 66.2 & 77.7 \\
\hline $\begin{array}{l}\text { 2. Income < AFDC } \\
\text { Threshold } \\
(\mathrm{n}=4,153)\end{array}$ & 64.1 & 31.8 & 26.2 & 39.7 & 83.4 \\
\hline $\begin{array}{l}\text { 3. Eligible Under } \\
100 \% \text { and } 133 \% \\
\text { Federal Program } \\
(\mathrm{n}=531)\end{array}$ & 30.0 & 24.3 & 19.9 & 81.2 & 75.9 \\
\hline $\begin{array}{l}\text { 4. Eligible Under } \\
100 \% \text { Program } \\
\text { Only }(n=383)\end{array}$ & 42.5 & 30.3 & 21.7 & 74.3 & 67.1 \\
\hline $\begin{array}{l}\text { 5. Eligible Under } \\
\text { 133\% Program } \\
\text { Only (n=665) }\end{array}$ & 23.3 & 17.2 & 17.9 & 116.1 & 61.6 \\
\hline $\begin{array}{l}\text { 6. Eligible Under } \\
\text { State Program } \\
(n=856)\end{array}$ & 24.7 & 10.8 & 26.7 & 150.6 & 67.1 \\
\hline $\begin{array}{l}\text { 7. NOT ELIGIBLE } \\
\text { Inc/POV <166\% } \\
(n=3,784)\end{array}$ & 33.4 & 25.2 & 17.4 & 118.2 & 21.3 \\
\hline
\end{tabular}


Table 9: Comparisons of Previous Program Participation Rates for Children in 1992 and 1993 SIPP Who Were Medicaid-Eligible in Month 16

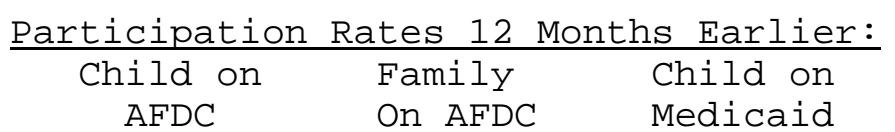

Basis of Eligibility

in Month 16:

1. All $(n=6,998)$

2. Income $<A F D C$ Threshold $(n=3,901)$

3. Eligible Under $100 \%$ and $133 \%$ Federal Program $(\mathrm{n}=512)$

4. Eligible Under $100 \%$ Program Only $(\mathrm{n}=565)$

5. Eligible Under 133\% Program Only $(\mathrm{n}=566)$

6. Eligible Under State Program $(n=1,454)$

7. NOT ELIGIBLE Inc/Pov <166\% $(n=3,575)$
33.4

48.0

15.8

23.1

10.5

12.4

9.7
37.2

50.6

52.8

64.6

8.4

46.8

$$
27.9
$$

44.7

Note: Sample includes dependent children under 18 in first interview who are interviewed in month 16 of the SIPP panels. 